\title{
PESQUISAS SOBRE PISO SALARIAL E REMUNERAÇÃO DOCENTE: UM ESTADO DA ARTE - 2008-2021
}

\section{ARTIGO ORIGINAL}

LIMA, Maria José Rocha ${ }^{1}$, RAMOS, Fernando Sadio²

LIMA, Maria José Rocha. RAMOS, Fernando Sadio. Pesquisas sobre piso salarial e remuneração docente: um estado da arte - 2008-2021. Revista Científica Multidisciplinar Núcleo do Conhecimento. Ano. 06, Ed. 11, Vol. 08, pp. 100-133. Novembro 2021. ISSN: 2448-0959, Link de acesso: https://www.nucleodoconhecimento.com.br/educacao/remuneracao-docente, DOI: 10.32749/nucleodoconhecimento.com.br/educacao/remuneracao-docente

\section{RESUMO}

Este artigo apresenta um levantamento acerca dos estudos sobre piso salarial e remuneração docente entre 2008 e 2021[3]. Neste sentido, a revisão de literatura sobre o piso salarial do magistério é uma peça fundamental. Para tanto, a metodologia desenvolvida para a busca bibliográfica tem como base o uso científico e cuidadoso da teoria Evidence-Based Practice (EBP) - em português, Práticas Baseadas em Evidências (PBE).Trata-se de um estado da arte que recorta um dos fatores mais decisivos para a transformação da realidade educacional: os estudos sobre piso salarial e remuneração dos professores brasileiros. Neste estudo, expõese mais uma contradição reinante entre os discursos enfáticos ou grandiloquentes em defesa da valorização do magistério e as práticas das autoridades políticas e

\footnotetext{
${ }^{1}$ Doutoranda em Educação na Universidade Internacional Iberoamericana - UNINI -; mestre em educação pela Universidade Federal da Bahia-UFBA-, Psicopedagogia pela Universidade Cândido Mendes - AVM, Especialista em Psicanálise pela Associação Brasileira de Estudos e Pesquisas em Psicanálise - ABEPP-, Especialista em Culturas Negras no Atlântico pela Universidade de Brasília - UnB-, Especialista em Metodologia do Ensino do Ensino Superior, pela Faculdade de Educação da Bahia - FEBA -, Licenciatura Plena para formação Especial no Currículo do 2 o Grau, na Área de Ciências da Saúde; Professora Primária, formada pelo Instituto Central de Educação Isaías Alves. ORCID ID: 0000-0003-1766-2169

${ }^{2}$ Orientador. Doutor em Ciências Sociais/Ciências da Educação, Programa Curriculum, Profesorado e Instituciones Educativas, pela Universidade de Granada, Espanha. Mestre em Filosofia Contemporânea pela Universidade de Coimbra, Portugal. Licenciado em Filosofia pela Universidade de Coimbra, Portugal. Diretor de DEDICA - Revista de Educação e Humanidades. (0000-0001-7654-5638) - ORCID

RC: 101410

Link de acesso: https://www.nucleodoconhecimento.com.br/educacao/remuneracaodocente
} 
educacionais, chamando-nos atenção, também, a baixa produção de monografias, dissertações e teses de doutorado, no mundo acadêmico, sobre piso salarial e remuneração docente. Mesmo com a proclamação da valorização do professor como fator decisivo para a garantia da qualidade da educação, passaram-se mais de dez anos desde o estabelecimento do piso salarial, contudo, cerca de $60 \%$ dos municípios brasileiros ainda não o implantaram e isso não tem a reverberação esperada nos estudos acadêmicos.

Palavras-chave: Estado da arte, Piso salarial, Remuneração docente, Salário do professor, Profissionalização do professor.

\section{INTRODUÇÃO}

No Brasil, lamentavelmente por iníqua tradição cultural, a garantia da educação como direito social se deu marcada por um atraso secular e uma lentidão impensável. As causas para tanto atraso educacional vêm sendo apontadas por teóricos, a exemplo do sociólogo Florestan Fernandes (1989, p. 160), que ao analisar a história brasileira, identifica a dependência econômica, o obscurantismo das classes dominantes e um permanente conflito levado para o interior da escola, que pouco ajuda na solução de problemas, como fatores do atraso. É como uma medição ininterrupta da correlação de forças. Assim, há disputas de projeto de escola, de projeto de valorização, ou não, do professor; projeto de sociedade; projeto de homem, enfim, como uma luta política incessante. O que um governo faz, outro desfaz. Que interesses são esses que movem a não aplicação da lei que instituiu o piso salarial? Estariam aqui expressas as disputas sobre as quais nos fala Florestan Fernandes, entre os céticos de direita ou de esquerda que, quase sempre, sabotam a educação no Brasil?

Em 1932, o Manifesto dos Pioneiros da Educação Nova, que teve entre os seus mais destacados subscritores Fernandes de Azevedo e Anísio Teixeira, inicia o documento clamando para que na hierarquia dos problemas nacionais, nenhum se sobrelevasse ao da educação, nem mesmo os de caráter econômico. O célebre pensador da educação Anísio Teixeira advertia que "sem educação, a democracia RC: 101410

Link de acesso: https://www.nucleodoconhecimento.com.br/educacao/remuneracaodocente 
seria uma palavra vã usada para justificar a farsa triste de um sufrágio universal irrisório" (LIMA, 2011, p. 66). Já para Florestan, "um ponto essencial é o que diz respeito à tradição cultural e ao que ela tem representado de limitação cultural do professor, menos na teoria, que na prática (FERNANDES, 1898, p. 157).

A visão do magistério como sacerdócio atravessou e se consolidou através dos séculos. Esta concepção religiosa e tradicional na cultura brasileira, construída bem nos primórdios da colonização, quando dirigida por religiosos, se constituiu em um dos graves problemas enfrentados pelos professores para a sua profissionalização e realização do trabalho escolar profissional. Nessa tradição era, e é, inaceitável ao professor discutir remuneração; o mestre deveria tomar o magistério como uma missão: ser idealista, ser pobre e feliz no exercício da profissão. Não é raro que o professor não tenha dinheiro sequer para comprar livros.

Em 1827, o Imperador Dom Pedro I outorgou a Lei das Escolas de Primeiras Letras, de 15 de outubro de 1827, estabelecendo no art. 3ํㅡ a remuneração dos professores, um piso salarial nunca implantado. O seu sucessor, Dom Pedro II, chegou a afirmar que "se não fosse imperador, desejaria ser professor" e que não conhecia "missão maior e mais nobre que a de dirigir as inteligências jovens e preparar os homens do futuro". O último monarca do Império do Brasil reinou durante quase 50 anos e nada de concreto fez pela remuneração e pelo reconhecimento do professor.

As belas e expressivas palavras pronunciadas e atos legislativos dos Imperadores do Brasil, de 1827 a 1889, não tiveram as repercussões anunciadas na política de remuneração dos professores. Apesar da não implantação do piso do magistério, foi emblemático o ato de criação do piso, em 1827. Tudo isto compõe as provas mais eloquentes desse desencontro entre o discurso e a prática na história política de remuneração dos professores das escolas públicas brasileiras.

As autoridades brasileiras discursam com eloquência sobre a importância do professor, contudo, 
realmente), mas sem a contrapartida de oferecer as condições necessárias a que o professor possa atuar na plenitude dos seus recursos e das suas qualificações (TEIXEIRA, 1999, p. 9).

Esses discursos, veiculadores, quase sempre, da visão do magistério como missão de caráter religioso e ou assistencialista/paternalista parecem funcionar, via de regra, inibindo os educadores, os acadêmicos, e até sindicalistas, de abordarem e defenderem salários, piso salarial, remuneração docente condigna para o magistério, de modo que, quando o fazem, é com certa tibieza.

A ideia sobre o "professor vocacionado", uma visão meramente subjetiva, repercute negativamente na tarefa pedagógica, constituindo-se numa barreira para a superação da visão errônea de que para ensinar, bastam algumas habilidades, sem levar em conta a complexidade da tarefa. Ensinar não é trabalho para pessoas leigas. A didática e a pedagogia são campos científicos com acúmulo significativo de conhecimentos.

Assim, dois graves desafios devem ser enfrentados para a realização do trabalho escolar profissional e a elevação da qualidade da educação: o não reconhecimento do magistério como profissão e a indefinição quanto à finalidade da escola. Para a superação desses dois problemas, há que se realizar um forte movimento que se contraponha à impensável situação que é o professor receber piso salarial quase sempre bem abaixo dos salários recebidos por profissionais com o mesmo nível de formação. Essa situação o obriga a trabalhar em várias escolas ao mesmo tempo e ainda a aceitar a realização do trabalho escolar em espaços inadequados.

Os professores trabalham sob as mais precárias condições: junto a sanitários fétidos, em escolas com salas divididas até por tabiques, sem água, sem sala de estar. Trabalham a maioria das vezes sem equipamentos básicos, como carteiras, mesas, armários, entre outros necessários. Em locais distantes, inóspitos e sem segurança, são comuns agressões e assaltos a professores no interior das escolas.

Em 2020, 4,3 mil escolas públicas não tinham banheiros, e a internet banda larga não chegava a 17,2 mil (20,5\%) em 2020. Além disso, 35.800 escolas seguem sem

RC: 101410

Link de acesso: https://www.nucleodoconhecimento.com.br/educacao/remuneracaodocente 
coleta de esgoto, 26,6\% do total, segundo o Censo Escolar de 2019. No que diz respeito aos recursos didático-pedagógicos, os professores, por não disporem deles, concorrem deslealmente com os recursos midiáticos, como estamos vendo neste período de pandemia. A Covid-19 expôs a trágica situação dos professores "de cuspe e giz", sem mapas, globos, ilustrações, em pleno século XXI, e na era da revolução tecnológica.

É fundamental ainda, para a resolução desses problemas, a definição clara da finalidade da escola. Para isto, é preciso estimular e elevar a produção científica e um movimento que promova a superação desta confusão estabelecida em relação à função da escola: lugar de proteção, abrigo, depósito para crianças ou espaço único para a realização de trabalhos escolares, que deve cumprir sua finalidade precípua de oferecer os conhecimentos técnicos e científicos e conteúdos necessários à sobrevivência simbólica.

Um dos discursos mais pervasivos para a desconstrução dessa visão do professorsacerdote foi pronunciado pelo professor da Universidade da Bahia - UFBA, jornalista e escritor João Carlos Teixeira, na Assembleia Legislativa da Bahia, em 1999, quando disse:

Por lamentável (e iníqua) tradição, no Brasil o professor costuma ser simultaneamente mártir e herói, quando deveria ser apenas (sobretudo) uma pessoa capacitada para o exercício da sua relevante missão social, prestigiada pela sociedade e amparada pelos poderes públicos, com remuneração à altura da importância de que o seu trabalho se reveste para toda a coletividade (TEIXEIRA, 1999, p. 9).

Somente no século XXI foi estabelecido por lei o Piso Salarial Profissional Nacional. Assim é que no dia 16 de julho de 2008, o então presidente da República, Luiz Inácio Lula da Silva, sancionou a Lei 11.738/2008. Lei essa que instituiu o Piso Salarial Profissional Nacional para os profissionais da educação pública básica PSPN -, estabelecendo um valor a ser, obrigatoriamente, reajustado a cada ano e "abaixo do qual a União, os Estados, o Distrito Federal e os Municípios não poderão fixar o vencimento inicial das Carreiras do magistério público da educação básica, para a jornada de, no máximo, 40 (quarenta) horas semanais" (BRASIL, 2008).

RC: 101410

Link de acesso: https://www.nucleodoconhecimento.com.br/educacao/remuneracaodocente 
Ainda assim, mesmo depois dessa espera secular, mais da metade dos 5.570 municípios brasileiros não o cumprem.

Diante desse cenário, e de acordo com o proposto, selecionamos os dez autores que mais publicaram sobre o Piso Salarial do Magistério Público da Educação Básica e buscamos apreender os resultados mais destacados por esses autores em relação à implantação do PSPN, criado pela Lei 11.738, de 16 de julho de 2008.

As pessoas, as autoridades educacionais, empresários, e principalmente os políticos fazem discursos eloquentes e adjetivados de reconhecimento ao professor, mas a prática é flagrantemente contraditória.

\section{PISO SALARIAL E REMUNERAÇÃO DOCENTE: UMA REVISÃO DE LITERATURA}

Conforme contextualizado anteriormente, o objeto deste trabalho é a implantação do piso salarial dos professores, sobre a qual apresentamos esta revisão da literatura. Para tanto, a metodologia desenvolvida para a busca bibliográfica tem como base 0 uso científico e cuidadoso da teoria Evidence-based practice $(E B P)$ - em português, Práticas Baseadas em Evidências (PBE) .

Destaca-se aqui que a discussão sobre buscas bibliográficas baseadas em evidências nasce a partir dos estudos da Medicina Baseada em Evidências (MBE) e se expande para outras disciplinas com o termo PBE. De acordo com Santos et al. (2007),

a PBE prevê metodologias e processos para a identificação de evidências de que um certo tratamento, ou meio diagnóstico, é efetivo, estratégias para avaliação da qualidade dos estudos e mecanismos para a implementação na assistência. (...) O movimento da PBE teve origem simultânea na McMaster University (Ontario, Canadá) e na University of York (Reino Unido). Evidência é aquilo que é claro, a constatação de uma verdade que não suscita qualquer dúvida. Evidência científica representa uma prova de que um determinado conhecimento é verdadeiro ou falso. Para que se tenha evidência científica é necessário que exista pesquisa prévia, conduzida dentro dos preceitos científicos (SANTOS et al., 2007).

RC: 101410

Link de acesso: https://www.nucleodoconhecimento.com.br/educacao/remuneracaodocente 
Neste sentido, a proposta foi realizar uma busca bibliográfica baseada em preceitos científicos com o objetivo de extrair do objeto principal "pagamento do Piso Salarial Profissional Nacional - PSPN", os trabalhos de pesquisa mais correlacionados e importantes para estudo.

Ademais, justificamos a adoção desta metodologia por existirem críticas às revisões de literaturas tradicionais, que não possuem metodologias específicas e explicitadas, demonstrando assim total aleatoriedade e viés em suas buscas. Santos et al. ( 2007) trazem à tona esta discussão quando expõe que:

As revisões de literatura tradicionais (hoje chamadas revisões narrativas) há muito são criticadas, uma vez que o método de busca bibliográfica e seleção dos estudos não são padronizados e explicitados. Os resultados obtidos com tais revisões são tendenciosos, não esgotam toda a literatura disponível sobre o tema pesquisado e geralmente são inconclusivos. A busca de evidência requer adequada definição da pergunta de pesquisa e criação de estrutura lógica para a busca bibliográfica de evidências na literatura, que facilitam e maximizam o alcance da pesquisa (SANTOS et al., 2007).

De acordo com Bariani et al. (2007), para as buscas bibliográficas baseadas em evidências, devem ser seguidas algumas diretrizes, como fizemos neste trabalho:

I. As buscas de literatura atualmente são em grande parte em diretórios online, isto é, em Bases de Dados on-line. Para este trabalho, realizamos uma busca no banco de dados da Capes, Scientific Electronic Library Online - Scielo, Google Acadêmico e Google Books.

II. Seleção de descritores, ou palavras-chave, alinhadas às especificidades do tema. Desta maneira, evitamos buscas com descritores amplos e generalistas.

III. Delimitação da tipicidade das palavras-chave, priorizando a utilização de substantivos e adjetivos; uso de palavras no singular e, por fim, evitando preposições, conjunções ou artigos.

IV. Verificação e validação das palavras escolhidas em sites de publicação nas principais áreas de estudo relacionadas à pesquisa.

RC: 101410

Link de acesso: https://www.nucleodoconhecimento.com.br/educacao/remuneracaodocente 
V. Filtragem da busca. A busca precisa ser bem delimitada, de modo que existem algumas formas que foram seguidas nesta pesquisa:

A) Busca do material no recorte temporal da pesquisa;

B) Busca exata dos termos. A busca exata é facilitada quando as palavras ou frases são escritas entre aspas;

C) Uso dos operadores lógicos booleanos AND, OR e NOT, onde se usa AND para localizar mais de um termo na mesma referência; NOT para excluir um termo comum de ser encontrado com a palavra-chave usada; e OR para excluir termos mais comuns de serem encontrados com a palavra-chave usada.

Quadro 1 - Expressões-chave da busca

\begin{tabular}{|l|l|}
\hline Piso salarial AND magistério & PSPN AND magistério \\
\hline $\begin{array}{l}\text { Piso salarial AND profissional } \\
\text { educação }\end{array}$ & PSPN AND profissional educação \\
\hline Piso salarial AND professor & PSPN AND professor \\
\hline Piso salarial AND docente & PSPN AND docente \\
\hline Piso salarial AND educador & PSPN AND educador \\
\hline Piso salarial AND trabalhador educação & PSPN AND trabalhador educação \\
\hline Piso salarial AND educação & \\
\hline
\end{tabular}

Fonte: Elaboração própria (2021).

A partir do tema Piso Salarial Profissional Nacional, foram delimitados os termoschave, que são Piso Salarial e PSPN. As buscas foram realizadas com o recorte de $1^{\circ}$ de janeiro de 2008 até $1^{\circ}$ de janeiro de 2021 no modo "busca avançada" no portal da CAPES, Scielo, Google Acadêmico e Google Books. Foram então categorizados como operadores booleanos os termos OR e AND. A combinação dos termos foi

RC: 101410

Link de acesso: https://www.nucleodoconhecimento.com.br/educacao/remuneracaodocente 
realizada a fim de pesquisarmos nas bases de dados os termos: Piso salarial ou PSPN, combinando a busca com os sinônimos conceituais sobre professores. Ademais, vale destacar que foram retiradas as preposições "da" e "de" para efeitos de refinamento da busca.

Após a busca das literaturas, foi criada uma base de dados com todos os artigos, teses e livros encontrados. Para a montagem do banco de dados foram desconsiderados trabalhos repetidos, publicações fora do período amostrado e que não estivessem publicados em português.

Com o intuito de ampliar o conhecimento sobre a literatura nacional, nossa pesquisa bibliográfica baseou-se na busca por artigos nacionais, monografias, teses, dissertações e livros que abordassem, de maneira contextualizada, o piso salarial. Este filtro foi elaborado a partir do título e do resumo de artigos científicos, teses, dissertações, monografias e livros.

Os descritores mais eficientes foram "piso salarial e magistério", "piso salarial e profissional da educação" e "piso salarial e professor". Os demais, "piso salarial e educador", "piso salarial e trabalhador da educação", "piso salarial e educação" retornaram, em conjunto, 12 resultados. Ao final, a busca totalizou 60 produções bibliográficas a serem analisadas.

Dentre as fontes de pesquisa utilizadas, o Google Acadêmico e o Google Books retornaram com maior volume de dados. Por isso, utilizou-se o critério de classificação por relevância do conteúdo seguido da seleção das dez primeiras obras que contemplavam os critérios e objetivos desta pesquisa. O recorte temporal foi de $1^{\circ}$ de janeiro de 2008 até $1^{\circ}$ de janeiro de 2021 , justificado pela data de início do piso e alongando-se até o período de alterações na Lei do FUNDEB.

Reconhecemos a limitação dos critérios de busca, embora entendamos que este é um esforço de concatenação das pesquisas e discussões alinhadas com o avanço das discussões sobre o piso salarial nacional. Foram desconsideradas artigos 
internacionais, notícias, produções que não tratassem de piso salarial no contexto brasileiro ou que o abordassem de maneira marginal.

\section{A PRODUÇÃO BRASILEIRA E SUAS CARACTERÍSTICAS}

Embora as abordagens e a consolidação de políticas de valorização docente tenham evoluído durante décadas, é a partir de meados de 2010 que a discussão na área de piso salarial e remuneração docente ganha maior corpo, o que reflete o crescimento de publicações, tanto em revistas científicas quanto em livros especializados.

a. Número de pesquisas ao longo dos anos

Ao longo dos anos, as discussões sobre a Lei do PSPN centralizaram-se na efetivação da política. Ao analisar as produções ao longo de 13 anos, observamos uma elevação das publicações nos anos de 2016 e 2019, quando comparado aos outros anos das publicações. Há uma elevação em 2016, cuja correlação possível são as eleições municipais e as mudanças que poderiam advir das novas gestões municipais. Outra possível ascensão em 2019 parece coincidir com a movimentação social e articulação sobre o Fundo Nacional de Desenvolvimento da Educação FUNDEB, que tinha, até aquele momento, caráter provisório. 
Gráfico 1 - Número de pesquisas ao longo dos anos

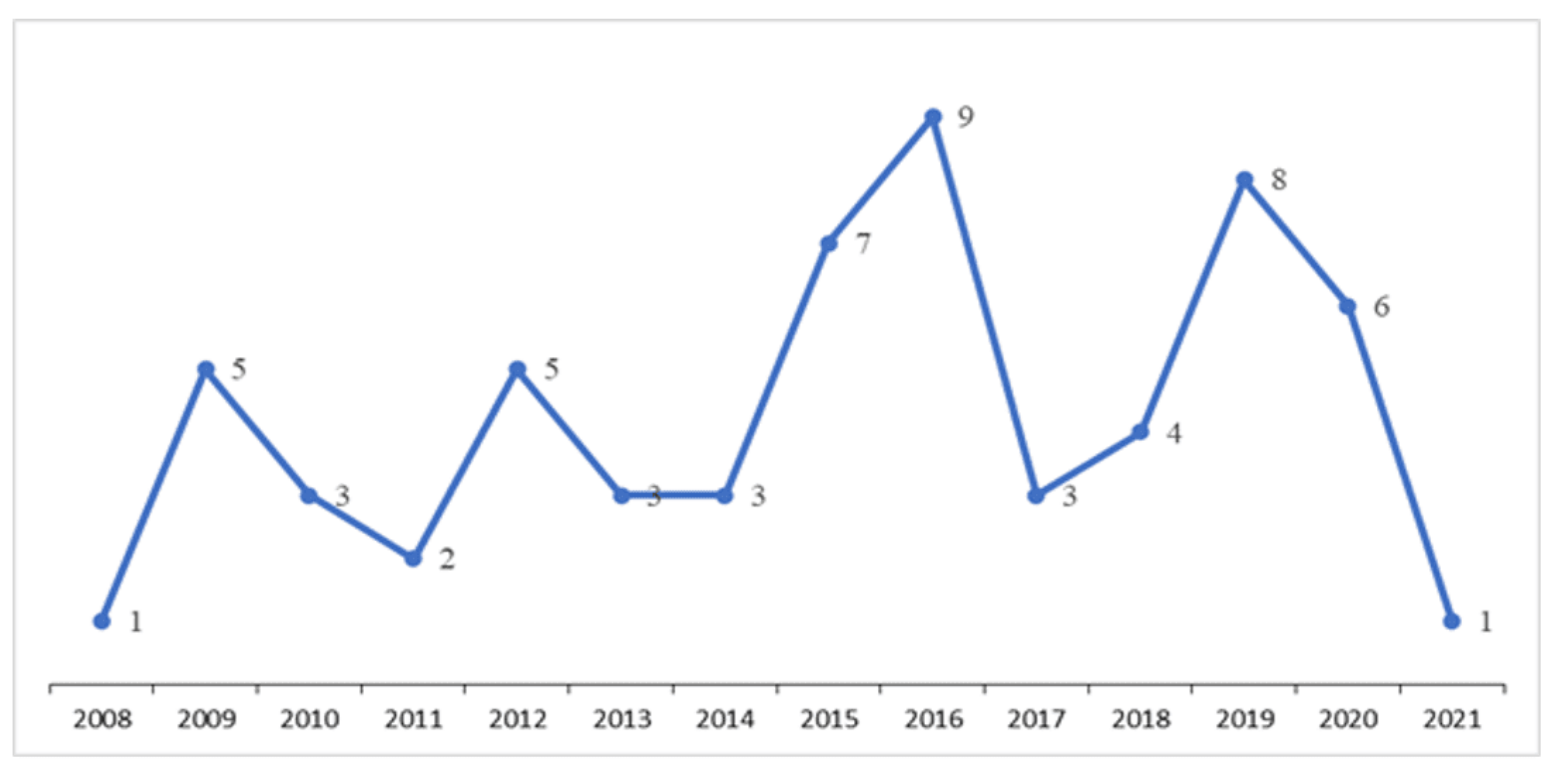

Fonte: Elaboração própria (2021).

b. Tipos de publicação

De forma geral, o tipo de publicação predominante são artigos e livros, representando $86,7 \%$ do conjunto total deste levantamento. Estes estudos foram impulsionados, em sua maioria, por produções na área de Educação. Teses, dissertações e monografias tiveram baixa representatividade no conjunto total deste levantamento em relação a artigos e livros.

RC: 101410

Link de acesso: https://www.nucleodoconhecimento.com.br/educacao/remuneracaodocente 
Gráfico 2 - Tipos de publicação

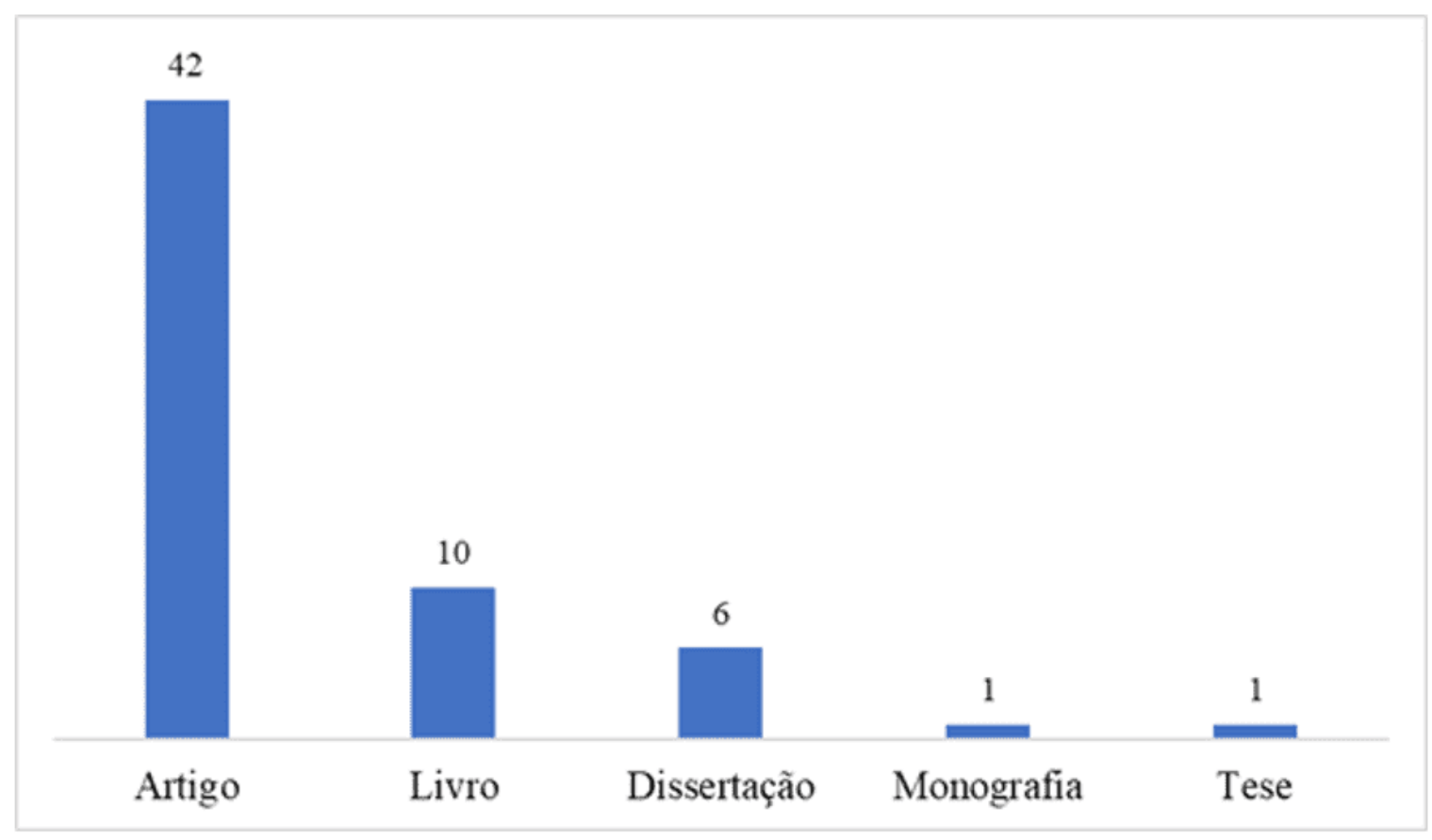

Fonte: Elaboração própria (2021).

c. Área de publicação

A pesquisa acadêmica no Brasil sobre o piso salarial está centralizada na área da educação, alcançando o índice de $80 \%$ (48 publicações). Do total de publicações sobre piso salarial na área de educação, 32 são de artigos e 10 são de livros. Logo, prevalece a produção de artigos e livros. Ademais, as áreas de Ciências Sociais e Ciências Políticas representam, em conjunto, 11,7\% (7 publicações). 
Gráfico 3 - Áreas de publicação

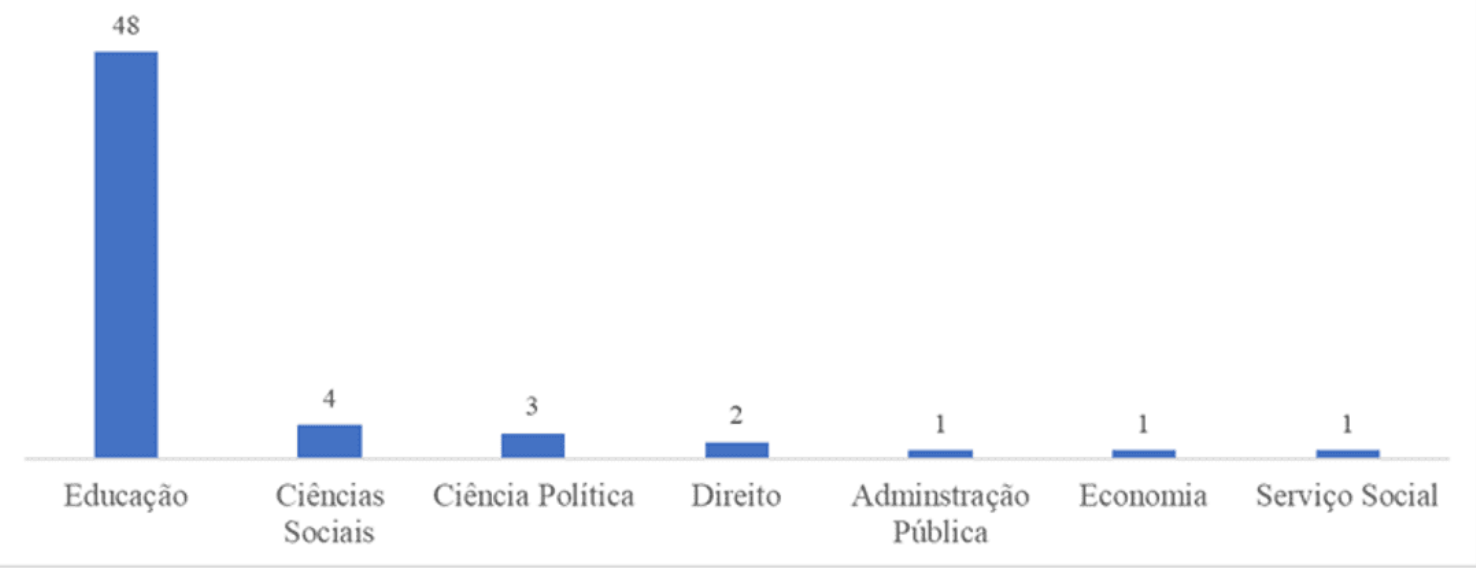

Fonte: Elaboração própria (2021).

Gráfico 4 - Áreas de publicação por tipo de publicação

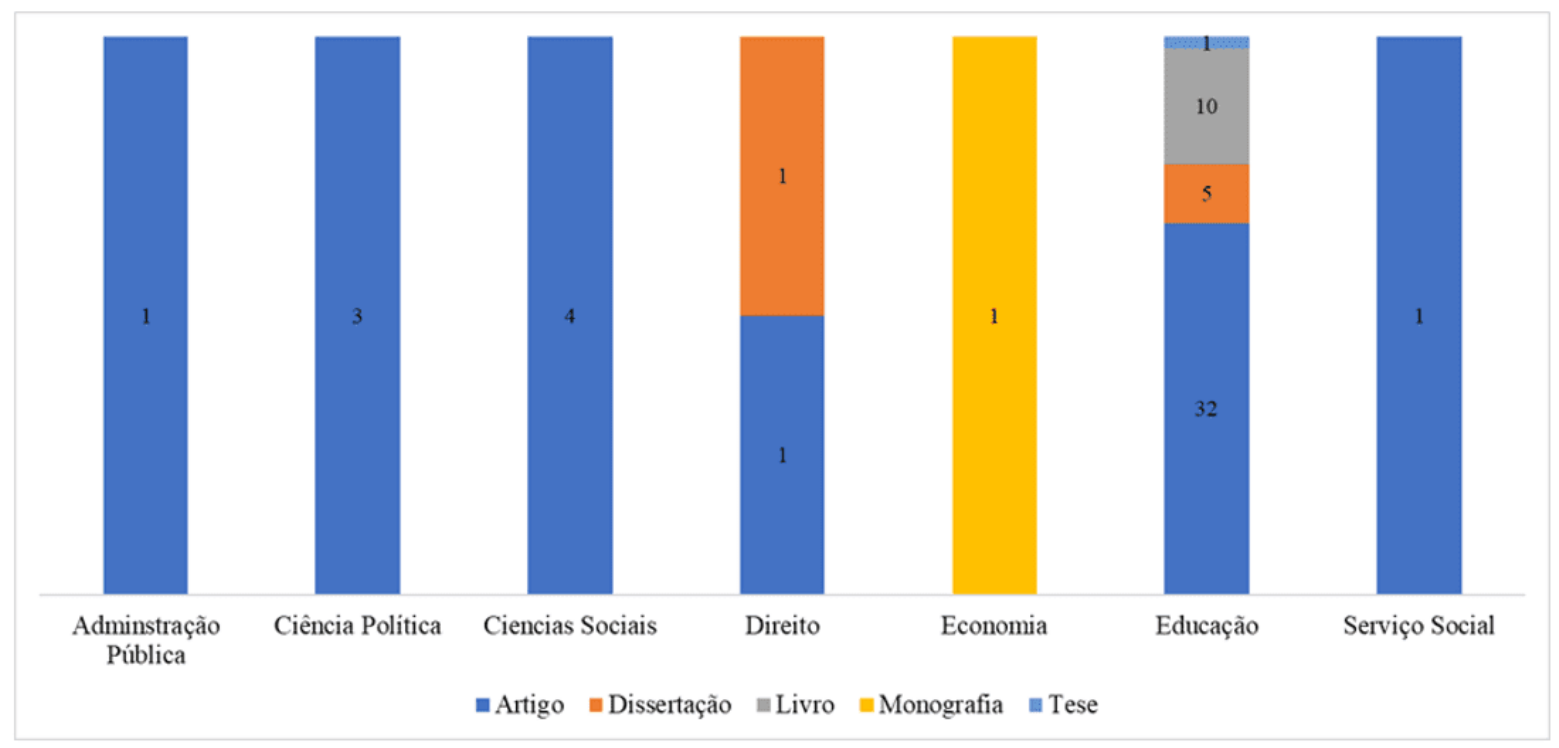

Fonte: Elaboração própria (2021).

d. Principais regiões de publicação

Ampliando a análise sobre a produção acadêmica nacional, observamos se os locais de publicação dos artigos, livros etc. tinham caráter regional ou nacional.

RC: 101410

Link de acesso: https://www.nucleodoconhecimento.com.br/educacao/remuneracaodocente 
Gráfico 5 - Regiões de publicação

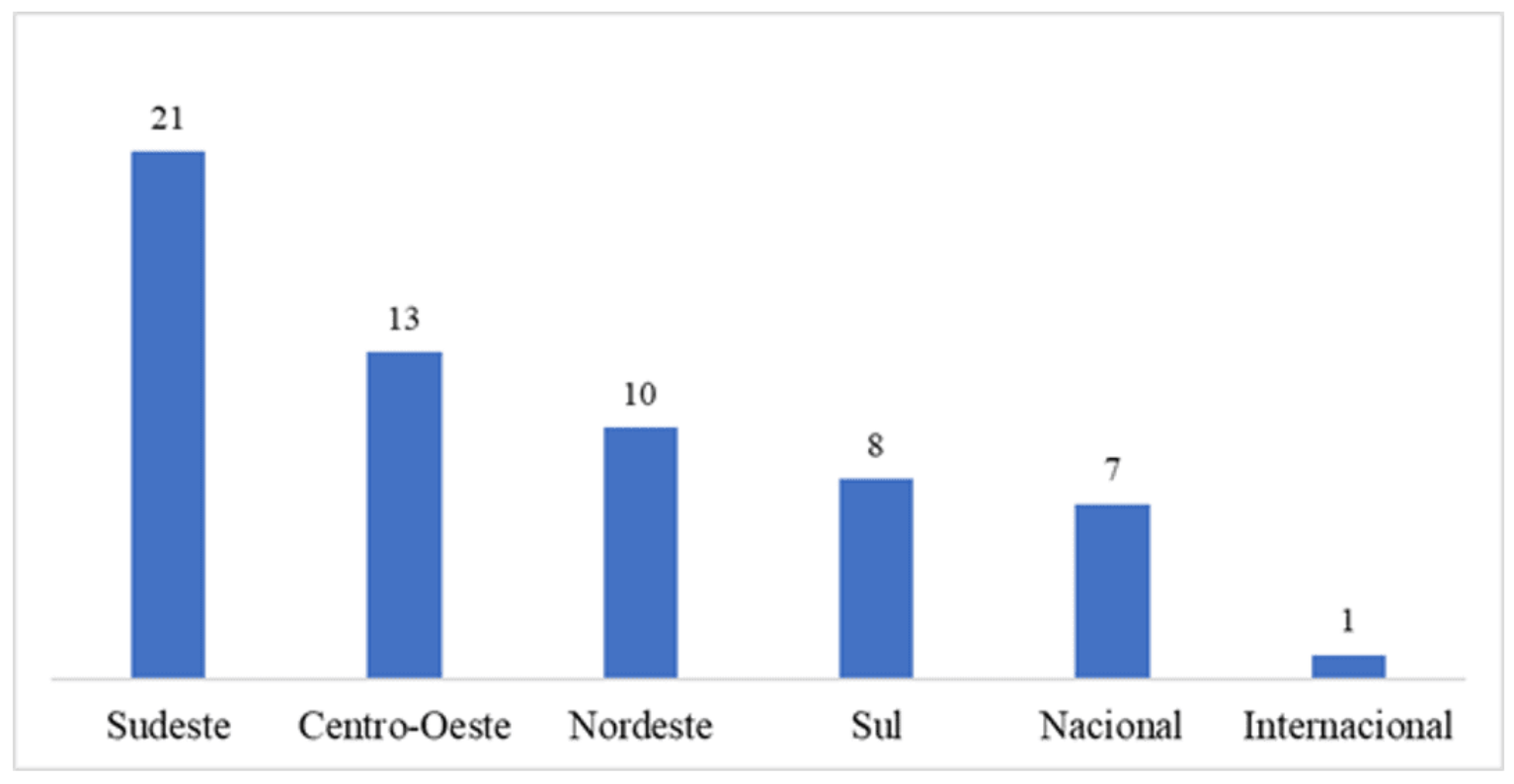

Fonte: Elaboração própria (2021).

A busca bibliográfica indica a Região Sudeste do país como um dos principais locais de publicação. Além do caráter nacional, também preponderam, em ordem decrescente, as Regiões Centro-Oeste, Nordeste e Sul.

e. Principais locais de estudo das publicações 
Gráfico 6 - Regiões de estudo das publicações

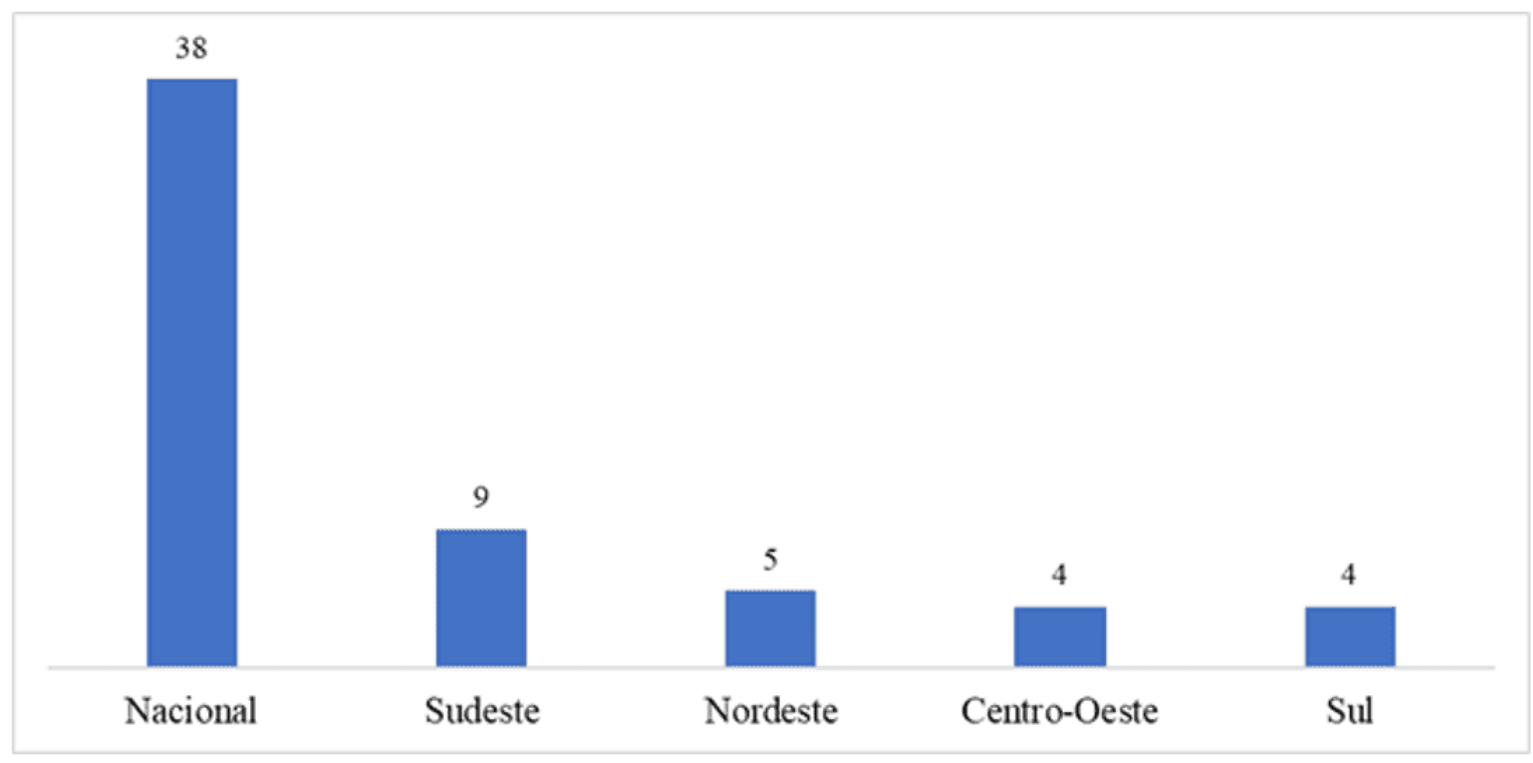

Fonte: Elaboração própria (2021).

De modo específico, e analisando os títulos e resumos das publicações, verificamos a tendência de estudos sobre a Lei do PSPN em caráter nacional (63,3\%). As análises regionais compreendem cerca de $36,7 \%$ do total de publicações. A Região Sudeste segue como foco de muitos estudos, e como pudemos identificar, destacam-se especialmente os Estados de São Paulo e Minas Gerais. Em seguida desponta a Região Nordeste, representando $8 \%$ no conjunto total de publicações, cabendo ressaltar os Estados da Bahia, Rio Grande do Norte e Piauí como foco de análise dos estudos regionais sobre o piso salarial. 
Gráfico 7 - UF de estudo das publicações

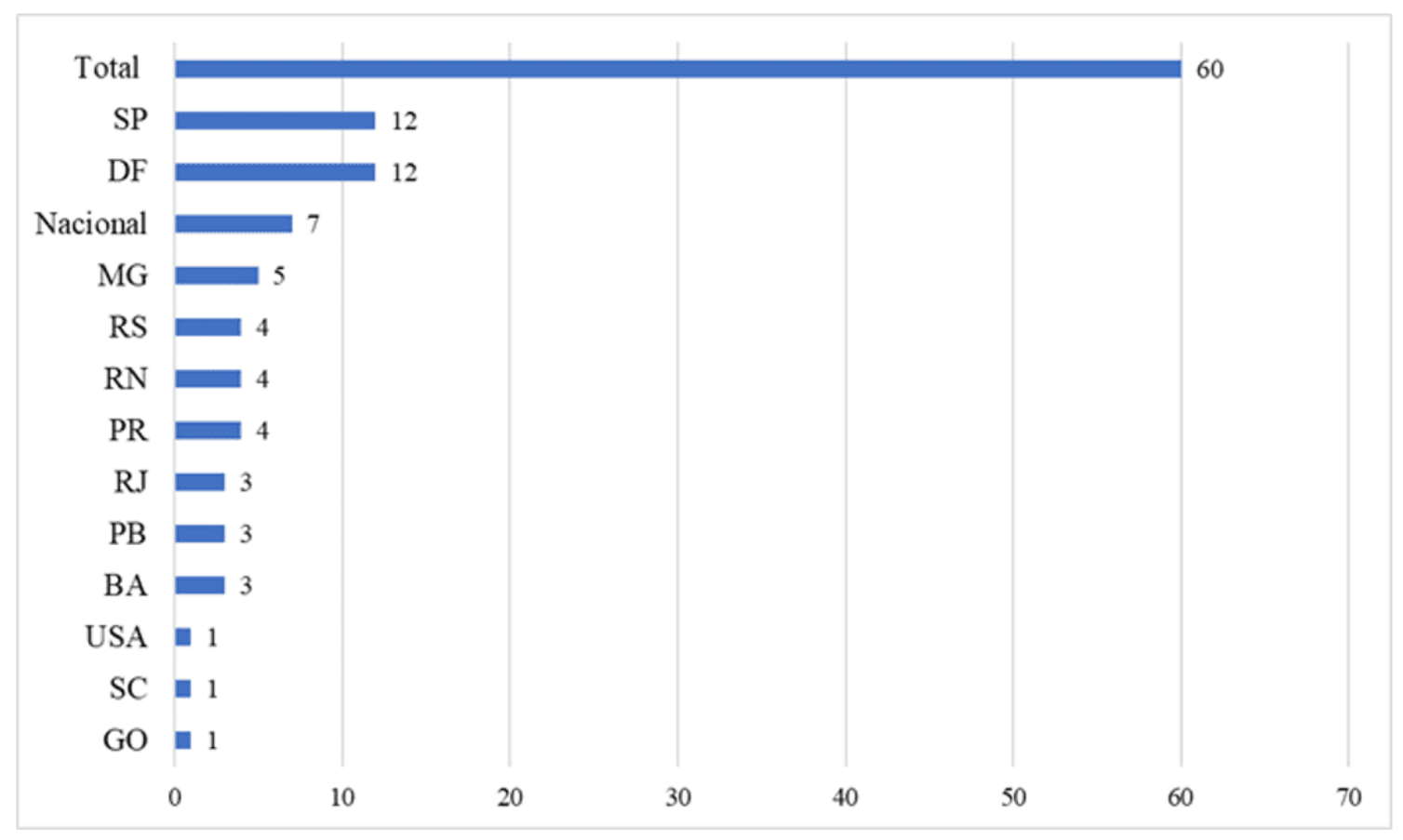

Fonte: Elaboração própria (2021).

\section{f. Principais autores}

A partir da identificação dos artigos, monografias, dissertações, teses e livros, foi possível levantar os nomes dos autores que os escreveram. Vale destacar que quando o trabalho possuía coautoria, como em alguns livros específicos, foram listados os nomes de todos.

Os autores foram então listados e agrupados de modo a obter o número de vezes que determinado autor publicou. Para tanto, criamos uma listagem com estes autores e elaboramos uma nuvem de palavras para visualizar aqueles de maior destaque. A nuvem de palavras ressalta, de maneira diretamente proporcional, a frequência de aparecimento das palavras. Assim, podemos observar que os dez autores com maior número de publicações são: Maria Dilnéia Espíndola Fernandes, Andréa Barbosa Gouveia, Márcia Aparecida Jacomini, Claudio Pinto Nunes, Eliara Cristina Nogueira da Silva Teixeira, Ana Paula Santiago do Nascimento, Andreza Barbosa, Áurea de Carvalho Costa e Dalila Andrade Oliveira. O ranqueamento dos RC: 101410

Link de acesso: https://www.nucleodoconhecimento.com.br/educacao/remuneracaodocente 
autores auxilia na delimitação dos autores e da bibliografia sobre piso salarial. Podemos perceber que a autoria é predominantemente de mulheres.

Figura 1 - Principais autores

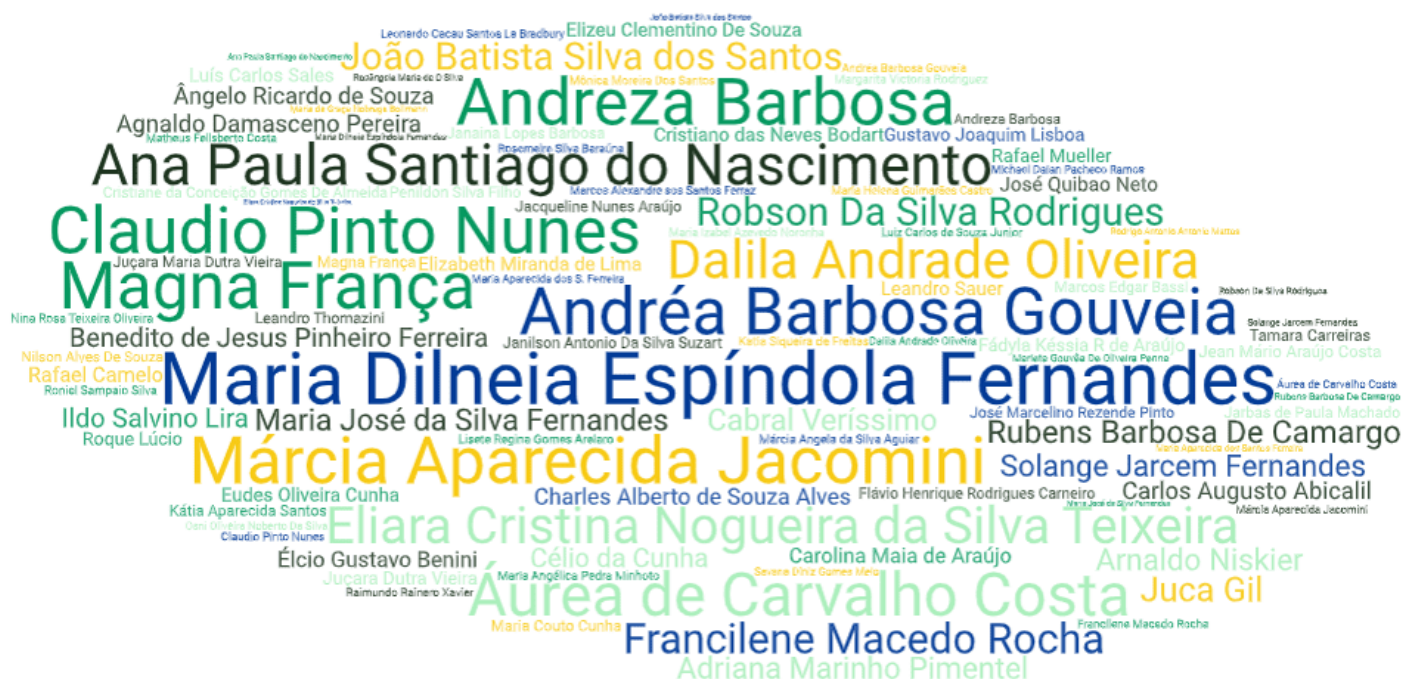

Fonte: Elaboração própria (2021).

\section{O PISO SALARIAL PROFISSIONAL NACIONAL E VALORIZAÇÃO DO PROFESSOR: O QUE DIZEM OS ACADÊMICOS}

A revisão de literatura tem um caráter qualitativo e exploratório e foi produzida para subsidiar os estudos de doutorado desta pesquisadora sobre a implantação da Lei 11.738/2008, que criou o Piso Salarial Profissional Nacional - PSPN. Para contextualizar a pesquisa, é importante que conheçamos como a questão relacionada à remuneração docente vem sendo abordada nas produções acadêmicas. Trata-se de uma pesquisa que teve inicialmente a única finalidade de contextualizar, situar os autores sobre a produção e posicionamentos acadêmicos, mas possibilitou comparar a produção dos discursos em política educacional e a verificação da sua aplicação prática no mundo acadêmico. Para este trabalho, foram selecionados os dez artigos de autores que mais produziram sobre piso, remuneração de professor e cumprimento da Lei do PSPN, entre os anos de 2008 e

RC: 101410

Link de acesso: https://www.nucleodoconhecimento.com.br/educacao/remuneracaodocente 
2021. São artigos que abordam a remuneração do professor e as suas relações com os fundos de financiamento da educação básica.

Afinal, o que dizem os acadêmicos sobre a remuneração do professor, considerando que foram quase dois séculos de lutas pelo Piso Salarial Profissional Nacional?

Em 15 de outubro de 1827, Dom Pedro I estabeleceu, no art. 3ํ da Lei das Escolas de Primeiras Letras, o primeiro piso salarial para o professor, mas esse nunca foi aplicado. A partir da Constituição de 1988, as discussões sindicais e acadêmicas ganharam contornos cada vez mais acentuados. Poucos foram os especialistas da área da educação que desvincularam a luta pela democratização da luta pela escola pública gratuita, com professores com formação inicial sólida e remuneração condigna. No dia 16 de julho de 2008, o então Presidente Lula sancionou a Lei 11.738/2008, que instituiu o Piso Salarial Profissional Nacional para os profissionais da educação pública básica, estabelecendo um valor a ser, obrigatoriamente, reajustado a cada ano e "abaixo do qual a União, os Estados, o Distrito Federal e os Municípios não poderão fixar o vencimento inicial das Carreiras do magistério público da educação básica, para a jornada de, no máximo, 40 (quarenta) horas semanais" (BRASIL, 2008). Embora o piso tenha sido instituído por lei desde 2008, mais de 10 anos após a sua sanção em mais da metade dos municípios, mais da metade dos municípios brasileiros transgridem a Lei do Piso, sem que haja qualquer punição.

Foram dois séculos de lutas dos professores pela criação do piso salarial para o magistério, mas, ainda assim, houve tentativas de alguns governadores de impedir a sua sanção, as quais felizmente foram frustradas.

Durante um trabalho de consultoria feito para a Unesco/MEC, constatamos que de 5.570 municípios, apenas 30\% cumpriam a Lei 11.738/2008 integralmente, isto é, pagando o piso inicial, criando novos planos de carreira, assegurando $30 \%$ da carga horária para estudos e planejamento, além da garantia da formação inicial sólida e ingresso por concurso público. Por isto, resolvemos estudar a implantação do piso salarial, e no caso da tese de doutorado[4] que estamos elaborando, especialmente RC: 101410

Link de acesso: https://www.nucleodoconhecimento.com.br/educacao/remuneracaodocente 
sobre o estado da Bahia, que é o $4^{\circ}$ maior estado da Federação e o maior do Nordeste brasileiro. Inicialmente, para subsidiar os estudos da tese citada sobre a implantação do piso nos 417 municípios baianos, buscamos uma base de pesquisa bibliográfica que alcançou dezenas de trabalhos. Já para este artigo, apresentamos os dez autores que mais produziram sobre o tema nesse período. Nesse contexto, o objetivo deste artigo é apresentar o desenvolvimento dessa linha de pesquisa, que consideramos relevante. Destacamos suas questões centrais, seus avanços e limitações, enfim, o estado da arte da literatura sobre o PSPN.

Apesar do dilema que envolve as influências da política sobre as políticas públicas para docentes e para a educação de qualidade, num país de "democracia restrita", como assinalou Florestan Fernandes (1987, p. 160), insistimos na busca de nexos que nos permitam a identificação do lugar ocupado pela valorização do professor e pela educação no universo acadêmico. Para responder à questão sobre o interesse dos estudos realizados sobre a implantação do Piso Salarial Profissional Nacional PSPN e se esses indicam as repercussões do piso salarial para a valorização do magistério, no período de 2008-2021, buscamos artigos, monografias, dissertações e teses da área das Ciências Sociais ou da Área da Educação.

Nos últimos quarenta anos, mais importantes autores, ainda que sejam poucos, vêm se empenhando na análise dos estatutos, programas, e práticas de gestores e buscando compreender a influência dos Partidos Políticos na explicação das variações dos resultados das ações governamentais na área da educação. Nesse período, sem dúvida, os estudos sobre práticas e políticas de educação vêm incluindo o professor, antes quase invisível. Prova disso foram os capítulos nas Constituição Federal e Constituições Estaduais que destacam a valorização do professor; a Lei de Diretrizes e Bases da Educação Nacional; a definição das Diretrizes Nacionais para a Formação de Professores; os Planos Nacionais de Educação do Brasil - PNE (2011-2020) e PNE (2014-2024) e a Lei 11.738/2008, que criou o piso salarial, documentos para os quais a qualidade da educação e a valorização dos professores constituem verdadeiros desafios. No novo Plano Nacional de Educação do Brasil - PNE (2014-2024), das 20 metas traçadas, 4 RC: 101410

Link de acesso: https://www.nucleodoconhecimento.com.br/educacao/remuneracaodocente 
dizem respeito ao professor, embora os Planos Nacionais de Educação venham sendo colocados de lado pelos governantes nas esferas federal, estaduais e municipais, e sendo transformados em meros protocolos de intenções.

A seguir, passamos às pesquisas dos acadêmicos sobre o PSPN, sobre a sua implantação, remuneração e valorização do magistério.

A Unesco publicou, na última década, dois trabalhos de fôlego: Professores do Brasil: impasses e desafios (2009), de Bernardete Angelina Gatti e Elba Siqueira de Sá Barretto, e Políticas Docentes - um estado da arte (2011), de Bernardete Angelina Gatti, Elba Siqueira de Sá Barretto e Marli Eliza Dalmazo Afonso de André. Esses estudos trazem uma radiografia dos trabalhadores da educação. Professores do Brasil: impasses e desafios (2009) mostra a dimensão do desafio que é a valorização dos professores e destaca que "os professores se encontram entre os grupos ocupacionais mais numerosos". E ainda há "os desafios de superação das conveniências políticas e de adotar estratégias articuladas entre as diferentes instâncias formadoras". Na conclusão, as autoras usam a palavra "trama", que é um desafio teórico e encontra-se no escopo do nosso trabalho. Em 1992, publicamos a monografia intitulada "A trama da ignorância" (LIMA, 1996), na qual analisamos discursos de autoridades brasileiras sobre o professor, no Império e na República, confrontando-os com as políticas efetivas de valorização do professor. Em 2011, as pesquisadoras Bernardete Angelina Gatti, Elba Siqueira de Sá Barretto e Marli Eliza Dalmazo Afonso de André publicaram o estudo Políticas Docentes no Brasil - um estado da arte, publicado pela Unesco e de grande abrangência. Nesse estudo, as autoras fazem um mapeamento e uma análise das políticas docentes aplicadas nas diferentes esferas federativas - União, Estados e Municípios - e colocam no centro da discussão a formação inicial e continuada do professor, a carreira do magistério e a avaliação dos professores. Nas conclusões, elas falam da diversidade de propostas de valorização docente, mas não se referem à implantação integral ou não da Lei 11.738/2008, que criou o Piso Salarial Profissional Nacional - PSPN -. E advertem: 
Se não houver aderência das propostas às políticas próprias dos estados e dos municípios, no caso das políticas federais, e destes últimos, no caso das políticas estaduais que a eles se estendem, ficam comprometidas a possibilidade de desenvolvimento profissional dos docentes e a sustentação das conquistas adquiridas (GATTI; BARRETO; ANDRÉ, 2011, p. 266).

O debate acadêmico sobre carreira e remuneração docente foi objeto de pesquisa dos autores Rubens Barbosa de Camargo, Andréa Barbosa Gouveia, Juca Gil e Maria Angélica Pedra Minhoto (2009). Nessa pesquisa, os autores analisam as relações entre os resultados do Fundef a partir de indicadores econômicos e remuneração docente, tendo como parâmetros as referências legais sobre o Piso Salarial Profissional Nacional. Para isto, os autores se valeram "dos indicadores econômicos nacionais, das remunerações docentes em redes estaduais e valores aluno-ano do Fundef'. E concluíram que as variações salariais são atinentes a cada um dos estados, apresentando uma inflexão positiva no sentido de recompor os salários, acima da inflação. Destacam a "necessidade de mais estudos para a compreensão da dinâmica da remuneração". Sobre a necessidade de mais estudos para subsidiar a fixação do piso salarial, cabe questionar se os especialistas esqueceram que os mestres esperaram dois séculos para conquistar o piso salarial estabelecido em lei, para todo o país.

Para os autores, "a remuneração docente, além de ter que ser melhor 'decifrada', para dar sustentação adequada à concepção de um PSPN, porque esta é determinada por fatores (externos e internos) envolvendo diferentes interesses" (CAMARGO et al., 2009). Tudo isto "para expor sua maior dimensão explicativa, revelando-a como expressão concreta de uma relação de forças em disputa de projetos de sociedade, de escola, de homem, de valorização do ensino: enfim, como luta política" (CAMARGO et al., 2009, p. 360). Que interesses são os que movem a não aplicação da Lei que instituiu o piso salarial? Estariam aqui expressas as disputas, sobre as quais nos fala Florestan Fernandes, entre os céticos de direita ou de esquerda que ajudam pouco, quase sempre sabotam a educação no Brasil?

Em artigo de 2010, Santiago do Nascimento, Amorim e Camargo (2010) analisaram a remuneração dos professores da rede estadual paulista no início da carreira e

RC: 101410

Link de acesso: https://www.nucleodoconhecimento.com.br/educacao/remuneracaodocente 
destacaram a sua composição com base no documento da Secretaria Estadual de Educação intitulado Sistema de Informações Educacionais - Boletim de Acompanhamento de Pessoal (novembro de 2010). Com isso, puderam verificar a evolução dos reajustes dos pagamentos recebidos pelos professores, no período entre 1996 e 2010.

Santiago do Nascimento, Amorim e Camargo (2010) constataram que "a remuneração era composta por diferentes gratificações que chegaram a representar mais de $35 \%$ do total". E que, em relação ao salário-mínimo, a remuneração sofreu um achatamento, passando de 3,6 em 1996 para 2,4 em 2010. Os autores pretendem contribuir para as discussões sobre remuneração dos professores no Brasil analisando os períodos por gestão, governadores e/ou secretários da educação. Na gestão do governador Mário Covas, a remuneração dos profissionais PEB I passou de $R \$ 360,94$ em 1996 para $R \$ 710,00$ no ano de 2000 e 2001, em valores nominais. Comparando esses valores, percebemos que a remuneração cresceu $96,71 \%$ em cinco anos.

No governo Alckmin, a remuneração dos profissionais PEB I passou de $\mathrm{R} \$ 710,00$ em 2001 para R\$ 1.144,39 em 2005 (NASCIMENTO; AMORIM; CAMARGO, 2010). $\mathrm{O}$ aumento foi de $61,18 \%$ em quatro anos. O vencimento passou de $\mathrm{R} \$ 610,00$ para $\mathrm{R} \$ 726,19$. Nesse período se teve o maior percentual de gratificações em relação à remuneração, com as gratificações chegando a representar $36,5 \%$ da remuneração dos professores.

No período do governo de José Serra, os pagamentos iniciais dos professores PEB I passaram de $R \$ 1.144,39$ em 2008 para $R \$ 1.198,16$ em 2010, em valores nominais. Analisando os vencimentos ( $R \$ 726,19$ e $R \$ 981,88$ ), percebemos um aumento de $35,21 \%$. A representatividade das gratificações no governo Serra passou de $36,5 \%$ em 2008 para $18,1 \%$ em 2010. Isso significa que esse governo teve uma política de incorporação das gratificações no vencimento, porém com possível perda real de poder de compra, conforme a relação com o salário-mínimo. A representatividade das gratificações no governo Serra passou de 35,5\% em 2008 para $17,4 \%$ em 2010.

RC: 101410

Link de acesso: https://www.nucleodoconhecimento.com.br/educacao/remuneracaodocente 
Assim, os autores concluem que em todo o período estudado, quando tomado como indicador o salário-mínimo (ou o salário necessário do Dieese), percebeu-se forte oscilação. Contudo, quando consideramos os anos de 1996 e de 2010, percebemos que couberam menos salários-mínimos, seja no vencimento ou na remuneração inicial, indicando um achatamento nos ganhos dos docentes paulistas.

Quando se trata de política de valorização do professor, as tensões são elevadas. Em artigo publicado por Maria Dilnéia Espíndola Fernandes e Margarita Victoria, com o título "O processo de elaboração da Lei ํo 11.738/2008, Lei do Piso Salarial Profissional Nacional para carreira e remuneração docente: trajetória, disputas e tensões", as autoras resgatam a trajetória recente da construção da Lei do Piso Salarial Profissional Nacional (PSPN) para a carreira e remuneração docente no Brasil, no contexto das reformas do estado brasileiro. Elas examinaram a legislação federal, documentos em âmbito federal e sindical e a literatura sobre o tema. Destacaram um dos confrontos políticos mais importantes na construção das relações federativas brasileiras naquele momento histórico, que foi uma Ação Direta de Inconstitucionalidade (Adin) contra a Lei n. 11.738/2008, impetrada por governadores dos estados do Mato Grosso do Sul, Paraná, Santa Catarina, Rio Grande do Sul e Ceará. Na Ação Direta de Inconstitucionalidade, os governadores questionavam o piso salarial nacional dos professores públicos de ensino fundamental, estabelecido pela Lei Federal 11.738/2008, discutindo sobre o alcance da expressão "piso" (art. $2^{\circ}$, caput e $\S 1^{\circ}$ ); a limitação ao valor pago como vencimento básico inicial da carreira ou extensão ao vencimento global; e a fixação da carga horária de trabalho. E alegavam a violação da reserva de lei de iniciativa do Chefe do Executivo para dispor sobre o regime jurídico do servidor público (art. 61, § $1^{\circ}$, ii, c da constituição); contrariedade ao pacto federativo (art. 60, § 4 e inciso da constituição); inobservância da regra da proporcionalidade: a jornada de trabalho e o salário instituído pela lei. As autoras entendiam "que o PSPN está implantado em termos de concepção". Com o Supremo Tribunal Federal, instância jurídica mais elevada do país, tendo aprovado a Lei no 11.738/2008 (BRASIL, 2008a), a contenda judicial foi resolvida, dando ganho de causa aos professores, assegurando-Ihes planos de carreira para o magistério público, piso salarial profissional e destinação RC: 101410

Link de acesso: https://www.nucleodoconhecimento.com.br/educacao/remuneracaodocente 
de $30 \%$ da carga horária para estudos e planejamento, além do ingresso na carreira exclusivamente por concurso público de provas e títulos. No dia 17 de dezembro de 2008, no voto do ministro Joaquim Barbosa estava escrito que "não é crível presumir que os estados federados se oponham à redução das desigualdades regionais, com a melhoria das condições sob as quais são prestados os serviços de educação pública". A implantação do piso nas diversas unidades subnacionais tem mostrado quão difícil é a superação dos localismos da tradição cultural brasileira na construção histórica do federalismo. Para elas, a viabilidade material do PSPN vai depender, ainda, de muito esforço por parte dos docentes da educação básica, bem como de possíveis alinhamentos nas relações políticas em torno do modelo de federação em vigor. O cenário nacional apresenta situações muito diversas no trato da questão salarial dos profissionais da educação básica. O que há em comum entre as unidades federadas sobre salários docentes é o baixo salário do professor.

A especialista Dalila Andrade (2013) publicou o estudo intitulado "As políticas de formação e a crise da profissionalização docente: por onde passa a valorização", no qual analisa a formação do professor e a relação com a profissionalização. No artigo, a autora busca compreender quais são os fatores que determinam a melhoria da educação. Ela critica "certas abordagens que põem o professor como o principal responsável pela tarefa educativa e, consequentemente, por seus resultados, deslocando o foco das estruturas e das relações sociais que envolvem o contexto escolar" (ANDRADE, 2013, p. 51).

Para Andrade (2013, p. 51), "a instituição da Lei do Piso Salarial Profissional Nacional e a criação do PARFOR são algumas das políticas orientadas na direção de maior valorização docente". Nessa pesquisa, a autora "procura discutir algumas correlações entre formação inicial e formação continuada com a remuneração, na tentativa de evidenciar seus nexos para maior valorização docente" (ANDRADE, 2013 , p. 51). E conclui que as atuais políticas educacionais visam atender às demandas por maior valorização docente. Depois da LDB 9394/96, o grau de instrução dos professores vem aumentando significativamente. Apesar disso, a legislação foi alterada permitindo que o professor com formação em nível médio 
passasse a ser, em alguns entes federados, regra e não exceção. Nisso a autora observa um retrocesso no plano legal. Ela conclui, com certa apreensão, mostrando preocupação com um afastamento dos pilares das políticas: carreira; condições de trabalho e remuneração, com um possível deslocamento "para um modelo de responsabilização dos docentes por sua formação, sobretudo a continuada, como forma de crescimento individual e profissional" (ANDRADE, 2013, p. 69). "Há um sentimento generalizado de que a profissão docente sofre um processo de desvalorização" (ANDRADE, 2013, p. 51). A análise dos dados da pesquisa mostrou que a correlação entre formação inicial superior (titulação) e a remuneração é segura. Diferentemente da formação continuada, que não apresenta correlação segura. Com isto, propõe-se repensar as políticas de formação continuada. A autora assinala que enfrentar a crise da carreira docente exige medidas efetivas de reforço à carreira, tanto nas formas de ingresso como na permanência do professor, na carreira, o que pressupõe condições de trabalho e remuneração.

Vemos que as políticas educacionais atuais devem buscar uma articulação entre as políticas de formação e as condições de profissionalização, dando maior peso à formação inicial sólida na definição e certificação da profissão. O ex-ministro da educação Rossieli Soares, do governo do presidente Michel Temer, apresentou, no Senado Federal, em 15 de maio de 2018, um documento intitulado "Panorama da Educação Brasileira". No documento, o MEC declarava 57 milhões de matrículas na rede pública, mas denunciava a baixíssima qualidade do ensino público, apontando entre as causas o alto percentual de docentes com formação inadequada, variando de $30 \%$ a $40 \%$. E metade dos professores de matemática não tinha formação para a área. O ex-ministro informou também que $80 \%$ dos professores da educação básica são formados em instituições privadas. Nos cursos de Pedagogia, das 690.780 matrículas, $80 \%$ destas estão na rede privada. Para Rossieli, as Universidades Federais precisam compreender que a formação de professores é uma estratégia de desenvolvimento nacional.

A pesquisadora Maria Dilnéia Espíndola Fernandes (2013), no artigo "A valorização dos profissionais da educação básica no contexto das relações federativo brasileiro", 
analisa, a partir de instrumentos jurídico-legais, a valorização dos profissionais da educação básica mediante a implantação do Fundeb e do Piso Salarial Profissional Nacional (PSPN) no contexto das relações federativas brasileiras. Após realizar uma pesquisa documental e revisar a literatura relativa ao tema, a. autora constatou que nas relações federativas brasileiras, as políticas educacionais poderiam contribuir para a colaboração federativa no que tange à redução das desigualdades sociais. $\mathrm{A}$ autora concluiu que "o exercício do poder local ainda se apresenta, muitas vezes, como um empecilho à coordenação federativa no que diz respeito à política educacional" e isto "determinaria o forte poder indutor da União frente, entre outras situações, à implantação do PSPN" (FERNANDES, 2013).

Em 2016, Andreza Barbosa e Maria José da Silva Fernandes, no artigo intitulado "Piso Salarial em São Paulo: desvalorização dos professores", publicado na revista Retratos da Escola, discutiram a situação atual dos salários e jornadas de trabalho dos professores na rede pública estadual no Estado de São Paulo para verificar a adequação à Lei oㅜ 11.738, de 2008, que criou o piso salarial do magistério. As autoras identificaram várias evidências revelando "que o governo do estado dribla sistematicamente a legislação federal, adequando, de forma questionável, a jornada de trabalho dos professores à lei do piso, e pagando, naquele ano, remuneração abaixo do estabelecido legalmente, o que amplia a desvalorização dos professores" (BARBOSA; FERNANDES, 2016, p . 243).

O trabalho de pesquisa intitulado "Financiamento da Educação e Luta Sindical: conflitos em uma grande rede de ensino", de Andréa Barbosa Gouveia e Marcos Alexandre dos Santos Ferraz, focalizando o impacto da lei do piso salarial profissional nacional sobre as disputas dos professores de Curitiba com o gestor da rede local de ensino, analisou as pautas de reivindicações do Sindicato dos Professores entre os anos de 2008 e 2012. Os autores centraram o seu foco nos itens relativos a piso e remuneração e implementação de $1 / 3$ de hora atividade. Foi possível observar diferentes maneiras de vocalizar as demandas de piso e diferentes impactos concretos sobre a remuneração. Em certos momentos, provocando achatamento da carreira e, em outros, achatamento do próprio piso. 
Quanto à hora atividade, esta deixa de ser uma reivindicação de organização do trabalho e assume a característica de um direito justo. Os autores concluíram que a maneira como eram construídas as pautas de reivindicações se alterou depois do reajuste do piso - sendo que, a partir de 2012, "após a mudança da forma de explicitar a reivindicação do piso, o índice de reajuste passa a incidir sobre toda a tabela salarial, sem distinção. Assim, o efeito de achatamento da carreira é contido" - e que a implementação de $1 / 3$ de hora atividade passa a ser tema importante, contundente nas reivindicações. Nas pautas anteriores a 2011, hora atividade se limitava a ser uma pauta de fiscalização do cumprimento da legislação municipal já vigente. Até 2011 , as reivindicações de reajuste de ordem salarial seguiam a lógica de soma de um conjunto de índices percentuais - índice de inflação do período, índice de ganho real, índice de perdas históricas. E até 2011, o reajuste do nível 1 da carreira (ou seja, o piso) sempre se comportava de forma diferente de outros níveis. Ou seja, o piso para o professor graduado é superior ao que ocorre nos demais pontos da tabela salarial (exceção feita ao ano de 2010). Isto significa que ocorreu valorização do piso, mas com achatamento da carreira. $O$ aspecto interessante é que na soma dos anos de 2009, 2010 e 2011, o nível 1 da carreira tem reajuste superior ao reajuste do piso nacional no mesmo período. A partir de 2012, este conceito de soma de vários índices é substituído por um único valor nominal de piso. O efeito destas duas estratégias distintas é diferente quando se observa o resultado final das negociações. Os autores concluem ainda que a pauta ganha a dimensão de reivindicação de um direito prescrito por lei e finalizam afirmando: "o caso específico da Rede Municipal de Curitiba e do SISMMAC mostra que os professores estão em contínua avaliação dos seus efeitos, assim como reavaliando suas próprias táticas e estratégias de lutas para poderem gozar um direito que a sociedade brasileira Ihes outorgou como justo" (GOUVEIA; FERRAZ, 2016).

Um dos artigos mais intrigantes foi publicado, em 2016, na revista Pro-posições, com o título "Análise da carreira docente e valorização do magistério: condições de trabalho e desenvolvimento profissional", de autoria de duas acadêmicas que estão na lista dos dez autores que mais publicaram sobre a valorização do magistério, RC: 101410

Link de acesso: https://www.nucleodoconhecimento.com.br/educacao/remuneracaodocente 
Márcia Aparecida Jacomini e Marieta Gouvêa de Oliveira Penna. As autoras abordaram vários aspectos referentes às condições de trabalho dos professores da educação básica no Brasil e seu desenvolvimento profissional, utilizando-se dos dados da pesquisa "Remuneração de professores de escolas públicas de educação básica: configurações, impasses, impactos e perspectivas", realizada em 12 estados brasileiros e suas capitais. Depois de analisarem os planos de carreira, verificando a formação exigida para o ingresso, jornada de trabalho, incentivos para a formação continuada e progressão na carreira, as autoras afirmam que "apesar da importância dos professores para a promoção de uma educação de qualidade, vários problemas ainda precisam ser enfrentados, a fim de garantir condições efetivas de trabalho aos docentes" (JACOMINI; PENNA, 2016). As autoras concluem o artigo citando uma pesquisa sobre condição docente em países como Argentina, Brasil, Peru e Uruguai, de Emílio Fanfani (2007, apud JACOMINI; PENNA, 2016), na qual este assinala que

toda política docente deve ser integral. Isto quer dizer que deve contemplar intervenções articuladas em pelo menos três dimensões: o recrutamento e a formação inicial e permanente, as condições de trabalho (divisão do trabalho pedagógico, carreira, contexto institucional, de trabalho, etc. e o sistema de estímulo e recompensa s materiais e simbólicas (salário e reconhecimento social).

Em outro parágrafo das considerações finais, as autoras supracitadas concluem que "pesquisas apresentadas no Brasil sobre as condições de trabalho do professor indicam desvalorização política e social da docência estruturando tal exercício profissional". E elas afirmam, sem entrar no mérito, que "o professor deve ter o salário em consonância com o valor e a importância que esses profissionais têm na sociedade contemporânea". As pesquisas indicam desvalorização do professor junto à sociedade contemporânea e que para mudar essa situação, é preciso o reconhecimento e a valorização da sociedade.

A análise sobre "Intencionalidades das políticas de valorização docente que foram efetivadas nos governos FHC e LULA, a partir das políticas de Fundos (Fundef e Fundeb)" foi objeto de estudo publicado por Teixeira e Nunes (2016). Nesse artigo, os autores examinam a questão salarial e de carreira dos professores da educação básica mediante a análise do lugar ocupado pelo Piso Salarial Profissional Nacional RC: 101410

Link de acesso: https://www.nucleodoconhecimento.com.br/educacao/remuneracaodocente 
(PSPN) nas agendas dos governos FHC e Lula. Verificaram ainda se as políticas aplicadas por esses governantes contribuíram para a melhoria salarial dos professores brasileiros. E concluem que o piso salarial nacional como medida de valorização do magistério recebeu abordagens diferentes nos governos de $\mathrm{FHC}$ e Lula. O Fundef, no governo FHC, embora tenha provocado melhoria salarial dos educadores, ressentiu-se de "uma referência nacional para o início de carreira, o que fez com que este Fundo não atingisse o seu objetivo de valorizar o magistério da educação básica". Já o Fundeb, no governo Lula, além de manter o mínimo de $60 \%$ dos recursos para pagamento dos professores, instituiu o prazo de um ano para criação do Piso Salarial em lei específica, o que culminou na Lei $n .0$ 11.738/2008, que estabeleceu a implantação do Plano de Cargos (TEIXEIRA; NUNES, 2016, p. 252).

Em artigo de Robson da Silva Rodrigues e Áurea de Carvalho Costa (2019) intitulado "Da Constituição Federal de 1988 ao Plano Nacional de Educação 20142024: ardilosas apropriações da noção de valorização do trabalho docente", os autores concluem que as políticas implantadas entre 1988 e 2014 promoveram desvalorização do magistério. A pesquisa teve como referencial teórico o materialismo histórico-dialético. Dizem os autores que ao observarem a atividade educativa nas práticas cotidianas, "aqueles que concretizam a prática educativa contradizem as políticas educacionais que diziam almejar a valorização dos professores. Esta contradição decorre da aplicação de noções de valorização esvaziadas de sentido axiológico". Nesses casos, bem de acordo com as legislações estatais, "o reconhecimento do valor do professor está relacionado às prescrições externas sobre o seu trabalho e que resultam em recompensas na forma de remuneração, benefícios e progressão na carreira, articulados à cultura do desempenho" (RODRIGUES; CARVALHO, 2019, p. 231).

Em estudo realizado por Andréa Barbosa Gouveia e Maria Dilneia Espíndola Fernandes (2019), a partir dos dados informados pela Relação Anual de Informações Sociais (RAIS, 2016) sobre salários dos docentes dos estados do Mato Grosso do Sul e Paraná, ficou demonstrado que a implantação e manutenção do RC: 101410

Link de acesso: https://www.nucleodoconhecimento.com.br/educacao/remuneracaodocente 
Piso Salarial Profissional Nacional vinham se dando por indução do Governo Federal e consequente atuação sindical. A agenda sindical docente incorporou a defesa do princípio da valorização profissional e construiu a necessidade de um Piso Salarial Profissional Nacional (PSPN) como um elemento estruturante. A regulamentação nacional do PSPN ocorreu em 2008; entretanto, devido ao pacto federativo brasileiro, o cumprimento da legislação depende dos governos locais. Isso implicou uma ampla mobilização dos sindicatos docentes para que a definição da remuneração incorporasse a regra nacional. Para as autoras, "o cenário de crise institucional instalado em 2015, seguido de uma agenda econômica restritiva para os direitos sociais, tem colocado em risco o conjunto de condições duramente conquistadas para a valorização dos professores" (GOUVEIA; FERNANDES, 2019, p. 89).

Em pesquisa realizada na Rede Municipal de Educação de Belo Horizonte RMEBH, as especialistas Francilene Macedo Rocha e Savana Diniz Gomes concluíram que "a lei do PSPN, diferentemente da valorização do magistério que preconizava, induziu a um rebaixamento na remuneração e restrição do horizonte de lutas dos professores pela carreira única dos professores da RMEBH, conquistada em 1996" (ROCHA; MELO, 2019, p. 3). Para as autoras, com a política de Piso Salarial Profissional Nacional ocorreu um processo de precarização do trabalho docente na RMEBH, a partir da segmentação da carreira docente em professor de ensino fundamental e professor para a educação infantil, o que rompeu a lógica da carreira única dos professores da RMEBH. Esse artigo apresenta uma discussão acerca das mudanças operadas na carreira e na remuneração dos professores da rede municipal de educação de Belo Horizonte (RMEBH) a partir de 2003, com a criação do cargo de educador infantil (EI), e de 2008 em diante, com a instituição da lei do piso salarial profissional nacional (PSPN). O período pesquisado foi de 2003 a 2016. Para a análise, as pesquisadoras tiveram como referencial teórico autores críticos clássicos, como Karl Marx e Friedrich Engels, e contemporâneos, como Oder dos Santos, João Bernardo e Ricardo Antunes, entre outros. Fundamentaram-se em bibliografia da área, em pesquisa documental com foco nas leis de âmbito nacional e municipal sobre carreira e da remuneração e publicações do Sindicato dos RC: 101410

Link de acesso: https://www.nucleodoconhecimento.com.br/educacao/remuneracaodocente 
Trabalhadores em Educação da Rede Pública Municipal de Belo Horizonte (Sind$\mathrm{REDE} / \mathrm{BH})$.

O artigo "Remuneração docente: efeitos do Plano de Cargos, Carreira e Remuneração em contexto municipal", de Maria Dilnéia Espíndola Fernandes, Solange Jarcem Fernandes e Viviane Gregório de Campos (2016), publicado na revista Ensaio: Avaliação e Políticas Públicas, foi elaborado a partir de um estudo de caso. Nesse estudo, as autoras buscaram verificar o efeito produzido pelos Planos de Cargos, Carreira e Remuneração (PCCR) implantados no município de Campo Grande, no período de 1996 a 2016, em termos de remuneração salarial para um professor ao longo de 20 anos de carreira. A análise da evolução da remuneração do professor foi feita a partir do exame dos seus holerites, cotejados com os PCCR e o salário-mínimo. As autoras constataram que houve um impacto positivo na remuneração do magistério, com a obrigatoriedade dos PCCR municipais, e que a titulação e o tempo de trabalho foram importantes para a valorização do professor. Permaneceu, contudo, em devir histórico no município, o pagamento integral do PSPN (Piso Salarial Profissional Nacional), que também deveria estar garantido por intermédio do PCCR.

\section{ALGUMAS CONSIDERAÇÕES}

A coletânea de artigos sobre a relevância dos estudos quanto à implantação integral do Piso Salarial Profissional Nacional - PSPN para os profissionais da educação básica corroboram, em certa medida, os resultados. No que diz respeito à desvalorização do professor e à compreensão do sentido de avaliar as repercussões do PSPN na sua valorização, as conclusões confirmam os estudos que consideram os modelos institucionais, as demandas sociais, as formas de governo, as políticas partidárias e os espectros político-ideológicos como influenciadores dos resultados, embora não sejam essas as únicas causas. Mais importante do que as características formais das instituições do estado e sociais é o modo como uma configuração institucional influencia as relações políticas. 
A redemocratização do país, a construção de um conjunto de leis e a observação do funcionamento das instituições transformaram o estudo das políticas públicas. Isto fica patente quando identificamos as variáveis institucionais formais ou informais nas análises dos fatores determinantes das políticas educacionais, a exemplo do comportamento do Poder Judiciário; da observação da estrutura federativa, com seus empecilhos; dos localismos em oposição à política de colaboração federativa; e dos grupos de interesses e dos confrontos de posições político- ideológicas que sabotam as políticas educacionais. Da mesma forma, a questão institucional serve para identificar similaridades entre as unidades de análise, possibilitando o foco apenas na variação de outras características desejadas, como partidos, eleições e condições socioeconômicas dos entes federativos.

Observamos uma quantidade expressiva de estados e municípios que aplicam o PSPN de acordo com os seus interesses e demandas sociais, muitas vezes, à revelia da lei. Em síntese, a complexidade das políticas partidárias nos impôs a necessidade de criarmos uma variedade de modelos e teorias para analisar seus processos e resultados, conforme ficou claro nas discussões de cada artigo. Tais estratégias analíticas, em diferentes medidas, se complementam e, ao mesmo tempo, corroboram o desenvolvimento conjunto e abrangente desse campo de pesquisa sobre as políticas públicas para a educação, particularmente sobre a correlação entre educação de qualidade e valorização docente.

\section{g. Principais tópicos abordados}

A busca bibliográfica incluiu a extração dos resumos dos textos e em especial das palavras-chave dos artigos, monografias, dissertações e teses. Quando analisados os livros, foram retirados os principais tópicos da indexação bibliográfica. Ao aglutinar todos os tópicos abordados, geramos a frequência de cada palavra-chave.

A nuvem de palavras a seguir permite ranquear os temas em seis assuntos mais relevantes. São eles: política educacional, trabalho docente, piso salarial, piso salarial profissional nacional, valorização do magistério e remuneração docente, os quais sugerem uma grande correlação com o objeto de estudo deste trabalho.

RC: 101410

Link de acesso: https://www.nucleodoconhecimento.com.br/educacao/remuneracaodocente 
Figura 2 - Principais palavras-chave

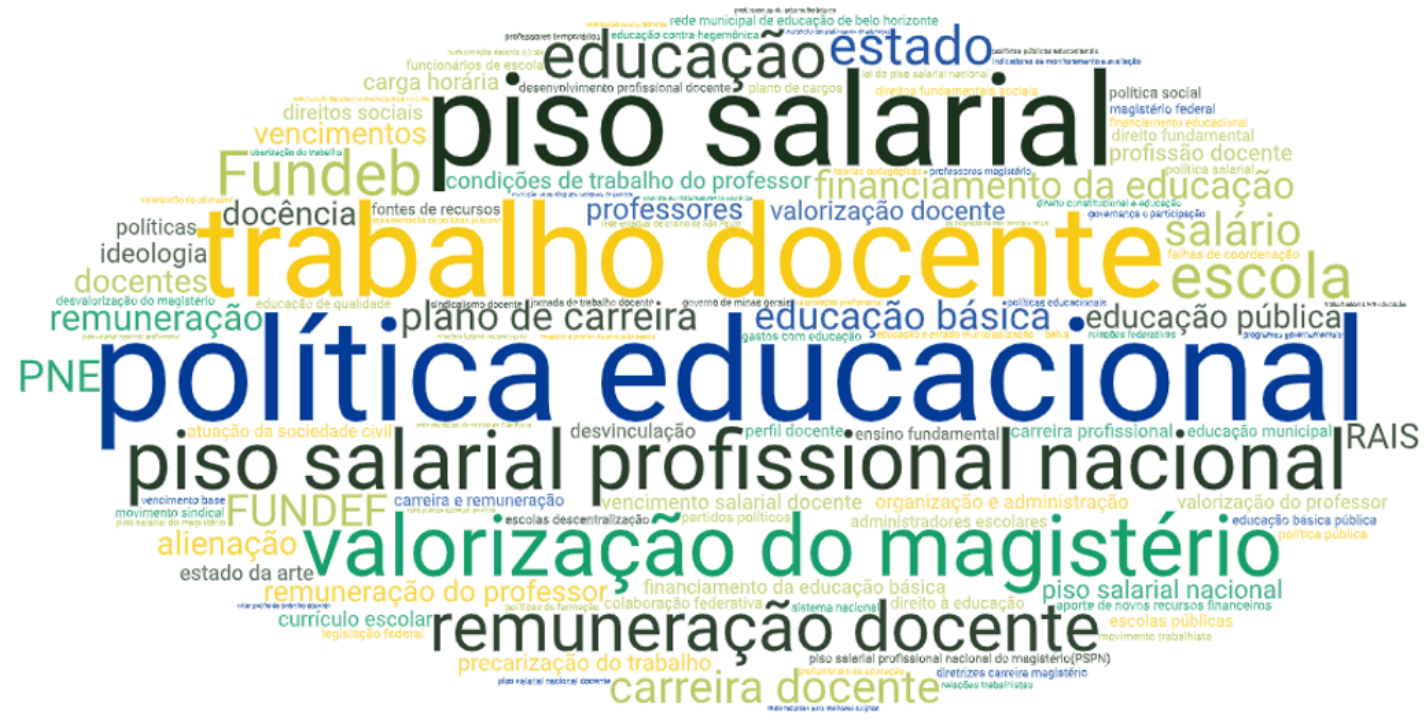

Fonte: Elaboração própria (2021).

Em que pesem tantas palavras da nuvem que exaltam a política educacional, trabalho docente, piso salarial, piso salarial profissional nacional, valorização do magistério e remuneração docente, esses vocábulos parecem não guardar a correlação esperada na produção acadêmica. Isto porque não produzem maiores impactos na produção de um número significativo de dissertações de mestrado e de teses de doutorado, estando esses estudos concentrados em artigos, ou nas indexações bibliográficas de livros.

$\mathrm{Na}$ experiência de mais de quarenta anos de militância na sala de aula do ensino primário, médio e superior - como dirigente sindical no estado da Bahia, vicepresidente da Confederação Nacional dos Trabalhadores em Educação (CNTE), deputada estadual de 1991- 1999, consultora legislativa na Câmara dos Deputados (1999 a 2003), Assessora Especial do Ministro da Educação (2003-2004), Assessora Especial da Presidência do INEP e Secretária Adjunta da Educação Profissional do MEC - esta pesquisadora conheceu empiricamente a tibieza de muitos especialistas da educação e autoridades educacionais, quando se trata de defender salários dignos para o professor. Conheceu também os impactos dessa concepção tão 
arraigada na tradição cultural do Brasil na pouco significativa produção acadêmica sobre o pagamento de salário, como se esse fosse um tema menor.

Nestas quatro décadas de militância na educação, esta autora conheceu dois renomados intelectuais brasileiros que defenderam remuneração digna para o professor, com desassombro: o sociólogo Florestan Fernandes e o filósofo Luiz Felipe Pondé. Florestan (1989, p. 58) considerava "o aviltamento salarial do professor de primeiro grau o mais deletério de todos". E Florestan concluiu: "poucos países reduzem o professor de primeiro grau a uma condição tão próxima da miséria relativa quanto o Brasil". Para ele, "o mesmo sucede com o professor de segundo grau, exposto a uma condição de insegurança e baixa remuneração sem paralelos. Esses graus de ensino são pilares da educação escolarizada". E Felipe Pondé entrevistado pela jornalista Thais Oyama, no Programa Linhas Cruzadas da Fundação Padre Anchieta (21/10/2021) denunciou que "tratar a profissão do professor e a educação como um tema idealizado, como sacerdócio, é uma estratégia de manter o professor pobre e feliz". O filósofo salienta que "é preciso dizer isto, porque no Brasil a condição de trabalho do professor acaba com a vida de qualquer pessoa. Os salários dos professores encontram-se entre os piores do mundo" (PONDÉ, 2021).

Pondé salienta que "esse tratamento produz pessoas desestimuladas; pessoas que sofrem muito para trabalhar; pessoas que não têm muito horizonte" (PONDÉ, 2021). Portanto, tão bom como estar na nuvem de palavras ranqueadas, esse deveria ser um tema central nas dissertações de mestrado e teses de doutorado, não apenas na área da educação, mas sobretudo na área do Direito Público. Afinal, não cumprir a Lei do Piso é uma transgressão inominável da lei; deveria ser objeto de estudos de mestrado e doutorado nas Ciências Sociais e Políticas, uma vez que isso põe em xeque a Política Nacional de Educação, a Constituição Federal e a Lei do Plano Nacional de Educação, consagradas por votações no Congresso Nacional. Deve-se salientar que não cumprir a Lei do Piso representa um desmonte da Política Educacional, uma vez que 4 (quatro) das 20 metas do atual PNE dizem respeito à 
valorização do magistério. Ademais, isso coloca em questão os programas partidários, prestando um verdadeiro desserviço à democracia.

As palavras mágicas utilizadas para inibir discussões, reivindicações e estudos acadêmicos sobre salário de professor são: sacerdócio e corporativismos. Essas estratégias vêm funcionando secularmente.

Portanto, esse resultado de palavras tão expressivas, na nuvem - na qual se sobressaem piso salarial, trabalho docente, política educacional, piso salarial profissional nacional, valorização do magistério, remuneração - não se articula com os resultados de buscas sobre os números e tipos de publicação extraídas dos resumos dos textos, das palavras-chave dos artigos, monografias, dissertações e teses e dos livros, dos quais foram retirados os principais tópicos da indexação bibliográfica.

\section{CONSIDERAÇÕES FINAIS}

Ao chegarmos a esta última parte do estudo, elaboramos reflexões e conclusões acerca dos Partidos Políticos e a implantação do piso salarial profissional nacional nos municípios - o discurso e a prática. Um considerável caminho foi percorrido em busca da construção de referencial teórico que permitisse não apenas expor a realidade dos professores quanto à implantação da Lei n. ${ }^{0}$ 11.738/2008, conhecida como Lei do Piso Salarial Profissional Nacional - PSPN na sua integralidade, dentro de um pequeno recorte temporal (2008-2018). Também buscamos expor a contradição entre os discursos dos políticos que inscrevem nos estatutos e programas partidários a defesa do magistério e o contraste das suas práticas no exercício do poder. A contradição se configura entre os discursos grandiloquentes de valorização do professor e as práticas, muitas vezes, aviltantes.

Em nenhum período histórico, como nas últimas décadas, a função do professor recebeu tanta ênfase nos debates sobre os sistemas nacionais e nas políticas educacionais e por diferentes atores, tanto públicos como privados, e de organismos nacionais, internacionais e multilaterais.

RC: 101410

Link de acesso: https://www.nucleodoconhecimento.com.br/educacao/remuneracaodocente 
A pesquisa demonstra a trajetória de descasos, lutas, derrotas e vitórias que precedeu à discussão e à aprovação da Lei no 11.738/2008. Da mesma forma, não seria possível apenas relacionar os partidos ao cumprimento da Lei, sem demonstrar o intricado sistema político partidário brasileiro, desde suas origens.

A relevância deste trabalho de pesquisa se mostra no sentido de avaliar os resultados das políticas para o magistério e para a elevação da qualidade da educação, especialmente na última década. Cabe destacar que o Plano Nacional de Educação tem quatro das suas vinte metas diretamente relacionadas à valorização do magistério. E mais outras duas outras, que têm repercussões indiretas.

Nessa perspectiva, a escolha desse tema representou a possibilidade de avaliação da gestão pública da educação e a confrontação dos discursos e práticas partidárias. Nesse sentido, pôde-se verificar a efetiva aplicação da política de valorização do magistério a partir de uma ferramenta criada pelo MEC com o objetivo de colocar à disposição dos municípios instrumentos para informação, acompanhamento, avaliação e monitoramento de políticas de melhoria da qualidade da educação: o Plano de Ações Articuladas - PAR/MEC.

Uma primeira conclusão é que, em que pesem tantas discussões e ênfase nas políticas de valorização, destacadamente a criação de lei estabelecendo o piso salarial para o magistério, está longe o alcance da efetiva valorização do professor.

A análise em 417 municípios do Estado da Bahia, realizada para fins de pesquisa voltada à elaboração de tese desta autora[5], permitiu reunir dados totais do maior dos estados do Nordeste brasileiro sobre a Implantação do Piso Salarial do Magistério Baiano, correlacionando-os aos Partidos Políticos à frente das prefeituras. Dos 417 municípios pesquisados, inclusive os sem partido, somente 146 (35\%) cumprem integralmente a Lei 11.738/2008; e dos 271 restantes, há 30 (7,1\%) que não deram nenhuma informação. Desse modo, pode-se afirmar que 241 $(57,7 \%)$ municípios não cumprem integralmente a Lei do Piso Salarial Profissional Nacional. 
Embora 180 municípios baianos afirmem que pagam o valor do PSPN, isso não significa o cumprimento integral da Lei, que só tem o seu pleno efeito legal se estiver articulada ao Piso Salarial, à definição de, no mínimo, 33\% da jornada como horas atividade (HA), e à garantia do Plano de Carreira. Destaca-se a existência de um único município que declara não ter Plano de Carreira, não cumprir HA e não pagar o PSPN.

Uma segunda conclusão importante, e os números mostram isso, é que apenas $35 \%$ dos municípios baianos cumprem a Lei do Piso Salarial Profissional Nacional dos Profissionais de Educação - PSPN, e quase $60 \%$, mais da metade dos municípios baianos, não cumprem integralmente a Lei $11.738 / 2008$, após 10 anos de sua sanção.

Possivelmente, o não pagamento do piso justifica porque a maioria dos professores entrevistados deseja que seja criada uma carreira nacional para o magistério, reclamando por uma nova lei. $O$ resultado da pesquisa amostral em 38 municípios possibilitou confrontar e corroborar todo o levantamento documental, bem como trazer a realidade dos profissionais que também atuam em instâncias sindicais, imprescindíveis nas lutas pela concretização do PSPN. Percebemos, nas falas dos professores sindicalistas, mesmo com algumas diferenças, o entendimento de que uma política de valorização que englobe cumprimento do piso, condições adequadas de trabalho e formação inicial e continuada, seriam fundamentais para a categoria. Do mesmo modo, a Carreira Nacional possibilitaria superar as dificuldades geradas pela autonomia descentralizada de que gozam os entes federados, pela ausência de um Sistema Nacional Articulado de Educação.

Outra importante conclusão da pesquisa é que são pouco significativas as diferenças entre os diversos partidos, quando examinamos as referências aos professores nos programas partidários. Dos 32 partidos que incluem a educação entre os temas abordados em seus Programas, apenas $12(34,2 \%)$ fazem alguma referência aos professores. Buscando por aqueles que citam "valorização, condições de trabalho, salário e formação", são 10 siglas partidárias na seguinte distribuição: 2 de esquerda, 3 de centro e 3 de direita. Observam-se diferenças pouco importantes RC: 101410

Link de acesso: https://www.nucleodoconhecimento.com.br/educacao/remuneracaodocente 
entre os partidos de direita, os partidos de centro, os partidos de centro-esquerda e de esquerda quando se trata dos discursos nos programas partidários e a efetiva aplicação da Lei 11.738/2008. Esse é um resultado não esperado, uma vez que os partidos de centro-esquerda e de esquerda sempre estiveram na vanguarda das lutas sindicais e parlamentares na defesa do Piso Salarial Profissional Nacional do Magistério.

$\mathrm{Na}$ obra de Florestan Fernandes (1979), buscamos compreender a razão dessa diferença pouco importante entre Partidos de direita, centro e esquerda, quando se trata da valorização do professor. Neste caso, quanto à aplicação de políticas permanentes de valorização do magistério e o motivo da não aplicação da Lei do Piso Salarial do Magistério pelos Partidos Políticos, inclusive aqueles que têm em seus programas a valorização do professor e discursam sobre ela como fator decisivo para a qualidade da educação, o que explica tantas contradições entre os discursos e as práticas de Partidos Políticos quando se trata da efetiva valorização do professor?

Para o sociólogo, fundador da sociologia educacional brasileira, deputado Constituinte do Partido dos Trabalhadores Florestan Fernandes, tínhamos sobre o professor um enigma a ser decifrado, que consistia na tradição de objetificação e brutalização cultural dos professores, própria da cultura brasileira. Depois de citar os escritos de Marx de 1844, Fernandes acrescenta que em uma comparação do professor com o proletário, é possível afirmar que o professor foi e ainda é objetificado na sociedade brasileira. Conduto, ele é um trabalhador intelectual, que não trabalha apenas com as mãos. O desafio é, conforme ele diz, buscar a compreensão dessa brutalização cultural, que ocorre há tanto tempo, e que é ainda mais pesada quando se trata de professores que se dedicam ao ensino de crianças, ou professoras primárias (FERNANDES, 1979).

O sociólogo afirma, aqui e ali, que membros leigos e letrados das camadas sociais dominantes se mostram tanto pessimistas quanto à eficácia das instituições brasileiras quanto indiferentes com o funcionamento das escolas e com o trabalho docente e discente (FERNANDES, 1979). Florestan denuncia ainda uma profunda RC: 101410

Link de acesso: https://www.nucleodoconhecimento.com.br/educacao/remuneracaodocente 
desconfiança da elite em relação ao intelectual. Para ele, a sociedade brasileira é fortemente desigual e muito hierarquizada. Se no Império, vigorava a democracia dos senhores, na República dominava a democracia dos oligarcas. A democracia brasileira é limitada e nela se dispensa uma cultura cívica, já que a ela somente uma minoria privilegiada tem acesso, em relação a riqueza, poder e saber (FERNANDES, 1989).

Assim, concluímos que no Brasil, tradição cultural e ceticismos parecem ser as causas da desvalorização do professor e da descrença do poder transformador da educação. Segundo Florestan, ceticismo ou dogmatismo em relação ao papel da escola nada significam nas dinâmicas de transformações sociais. Como um reforço a essas palavras, o educador Dermeval Saviani (1987) adverte sobre a necessidade de que as lideranças dos movimentos populares superem a visão da escola como um mero instrumento de dominação burguesa, que só desperta o interesse da população por sua capacidade de propiciar ascensão social. Nesse ponto pode ser encontrada a resposta à quase insignificante diferença entre os partidos de direita, centro e esquerda, quando se trata da aplicação do Piso Salarial dos Profissionais de Educação, que não se restringe à remuneração, mas à carreira, jornada de trabalho, formação e valorização do magistério e consequente melhoria da qualidade da educação.

\section{REFERÊNCIAS}

BARBOSA, Andreza; FERNANDES, Maria José da Silva Fernandes. O Piso Salarial em São Paulo: desvalorização dos professores. Retratos da Escola, Brasília, DF, v. 10, n. 18, p. 243-257, jan./jun. 2016.

CAMARGO, Rubens Barbosa de; GOUVEIA, Andréa Barbosa; GIL, Juca; MINHOTO, Maria Angélica Pedra. Financiamento da educação e remuneração docente: um começo de conversa em tempos de piso salarial. Revista Brasileira de Política e Administração da Educação - RBPAE, v. 25, n. 2, p. 341-363, mai./ago. 2009.

RC: 101410

Link de acesso: https://www.nucleodoconhecimento.com.br/educacao/remuneracaodocente 
FERNANDES, Florestan. O dilema educacional brasileiro. In: PEREIRA, Luiz; FORACCHI, Marialice M. (Orgs.). Educação e sociedade: leituras de sociologia da educação. 10. ed. São Paulo: Nacional, 1979.

FERNANDES, Florestan. O dilema educacional. São Paulo: Cortez; Autores Associados, 1989.

FERNANDES, Maria Dilnéia Espíndola; FERNANDES, Solange Jarcem; CAMPOS, Viviane Gregório de. Remuneração docente: efeitos do Plano de Cargos, Carreira e Remuneração em contexto municipal. Ensaio: Avaliação e Políticas Públicas em Educação, Rio de Janeiro, v. 28, n. 106, p. 25-44, jan./mar. 2020.

FERNANDES, Maria Dilnéia Espíndola; RODRIGUEZ, Margarita Victoria. O processo de elaboração da Lei no $11.738 / 2008$, Lei do Piso Salarial Profissional Nacional para carreira e remuneração docente: trajetória, disputas e tensões. Revista HISTEDBR On-line, v. 41, p. 88-101, 2011. Disponível em: https://periodicos.sbu.unicamp.br/ojs/index.php/histedbr/article/ view/8639837. Acesso em: 26 set. 2021.

GATTI, Bernardete Angelina; BARRETTO, Elba Siqueira de Sá; ANDRÉ, Marli Eliza Dalmazo de Afonso. Políticas docentes: um estudo da arte. Brasília: Unesco, 2011.

GATTI, Elba Siqueira de Sá Barreto. Professores do Brasil: impasses e desafios. Brasília: Unesco, 2009.

GOUVEIA, Andréa Barbosa Gouveia; FERRAZ, Marcos Alexandre dos Santos. Financiamento da educação e luta sindical: conflitos em uma grande rede de ensino. Educação \& Sociedade, Campinas, v. 37, n. 134, p. 285-302, jan.-mar. 2016. Disponível em: https://www.scielo.br/j/es/a/mvMXV3kDKSmkqbWBq3SvQLL/?lang=pt. Acesso em: 26 set. 2021.

GOUVEIA, Andréa Barbosa; FERNANDES, Maria Dilneia Espíndola. Agenda Sindical de Professores da Educação Básica: desafios postos a partir do Piso RC: 101410

Link de acesso: https://www.nucleodoconhecimento.com.br/educacao/remuneracaodocente 
Salarial Profissional Nacional. Práxis Educativa, Ponta Grossa, v. 14, n. 1, p. 84-98, jan./abr. 2019.

Disponível em: http://www.revistas2.uepg.br/index.php/praxiseducativa. Acesso em: 26 set. 2021.

JACOMINI; Márcia Aparecida; PENNA, Marieta Gouvêa de Oliveira Penna. Carreira docente e valorização do magistério: condições de trabalho e desenvolvimento profissional. Pro-posições, v. 27, n. 2, p. 177-202, maio/ago. 2016.

LIMA, Maria José Rocha. A trama da ignorância e outros escritos. Salvador: BDA, 1996.

NASCIMENTO, Ana Paula Santiago do; AMORIM, Renata Rodrigues de; CAMARGO, Rubens Barbosa de. Composição salarial dos docentes da Rede Estadual Paulista: uma análise a partir do Boletim de Acompanhamento de Pessoal da SEE/SP, 1996/2010. Fineduca - Revista de Financiamento da Educação, Porto Alegre, v. 4, n. 7, 2014.

OLIVEIRA, Dalila Andrade. As políticas de formação e a crise da profissionalização docente: por onde passa a valorização? Educação em Questão, Natal, v. 46, n. 32, p. 51-74, 2013.

RODRIGUES, Robson da Silva; COSTA, Áurea de Carvalho. Da Constituição Federal de 1988 ao Plano Nacional de Educação 2014-2024: ardilosas apropriações da noção de valorização do trabalho docente. Política \& Trabalho - Revista de Ciências Sociais, n. 50, p. 231-248, jan./jun. 2019.

TEIXEIRA, Eliara Cristina Nogueira da Silva; NUNES, Cláudio Pinto Nunes. O piso salarial como insumo da valorização docente nos governos de FHC e Lula: da Política de Fundos à Lei do Piso. Práxis Educacional, v. 12, p. 251-270, 2016.

\section{APÊNDICE - REFERÊNCIA NOTA DE RODAPÉ}

3. Este artigo é parte do trabalho de pesquisa realizado para a Tese de Doutorado em Educação intitulada Partidos Políticos e Piso Salarial do Magistério Baiano: RC: 101410

Link de acesso: https://www.nucleodoconhecimento.com.br/educacao/remuneracaodocente 
no Discurso e na Prática, que se encontra em etapa final de preparação e será defendida na Universidade Internacional Iberoamericana (UNINI).

4. Vide nota de rodapé no 1 .

5. Cf. nota de rodapé no 1 .

Enviado: Outubro, 2021.

Aprovado: Novembro, 2021. 